DOCUMENT:

TITLE:

REVISION NUMBER:

TASK:

TASK NUMBER:
WSRC-TR-93-174

Heat Loading Limits For Solid Transuranic Wastes Storage (U)

0

Heat Loading Limit Calculation for Storage of Solid Transuranium Wastes

93-013-1

\title{
Heat Loading Limits for Solid Transuranic Wastes Storage (U)
}

by

Thomas L. Spatz

KEYWORDS:

Blackbox

Conduction

Convection

Culvert

Cut

Drum

Poly-box

Thermal Conductivity

DOES NOT CONTAIN

UNCLASSIFIED

Thermal Radiation

Transuranic

Wastes

RETENTION:

Permanent 
DOCUMENT:

TITLE:

REVISION NUMBER:

TASK:

TASK NUMBER:
WSRC-TR-93-174

Heat Loading Limits For Solid Transuranic Wastes Storage (U)

0 Heat Loading Linit Calculation for Storage of Solid Transuranium Wastes 93-013-1

\section{Heat Loading Limits for Solid Transuranic Wastes Storage (U)}

by

Thomas L. Spatz

APPROVALS

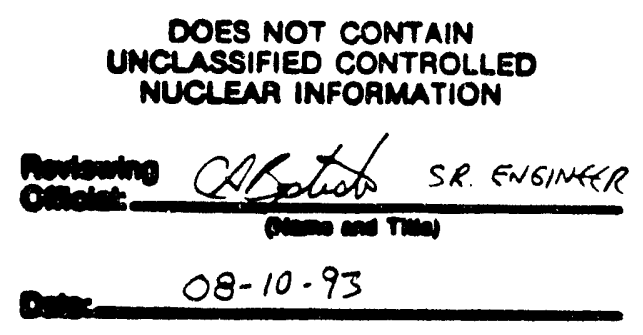

-1) fleflecer

D.R. MUHLBAIER, GROUP MANAGER

$\frac{\text { dJ Jawett }}{2 / 26 / 93}$
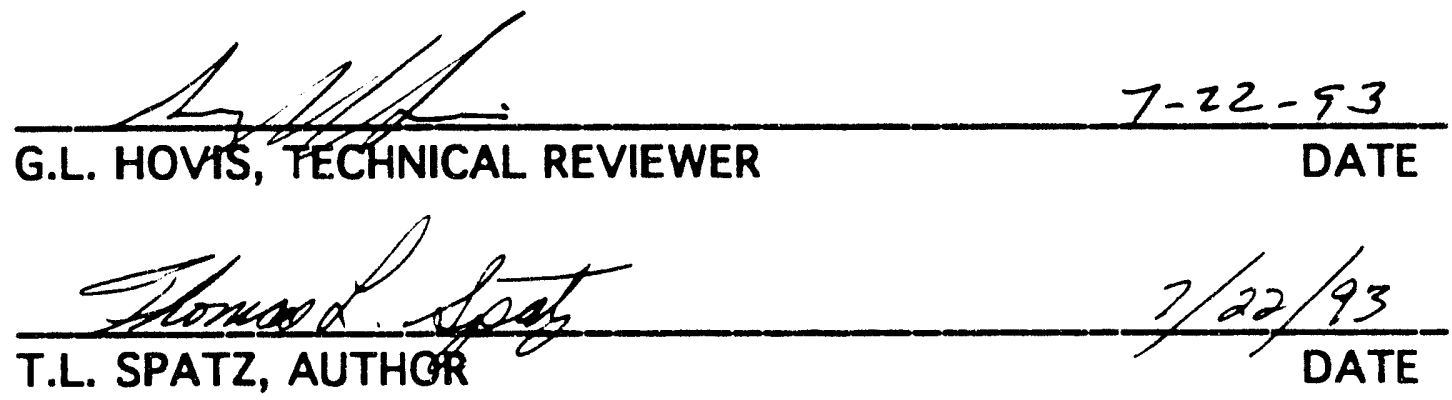


\section{Table of Contents}

1.0 Summary

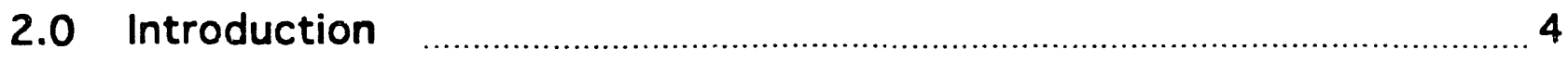

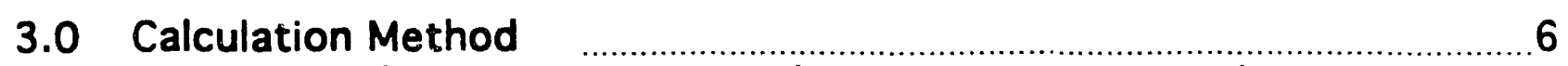

3.1 55 gallon drums in concrete culvert on open TRU pad $\quad$.......... 8

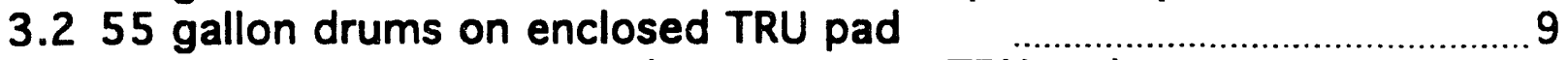

3.3 Poly-boxes in concrete culvert on open TRU pad

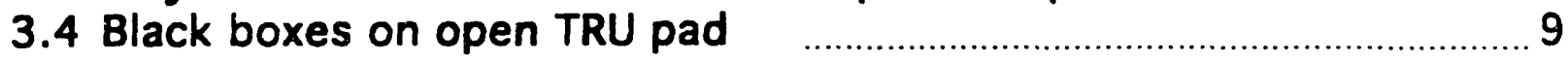

4.0 Results 9

4.155 gallon drums in concrete culvert on open TRU pad $\quad$.........10

4.255 gallon drums on enclosed TRU pad …….......................... 11

4.3 Poly-boxes in concrete culvert on open TRU pad $\quad \ldots \ldots \ldots \ldots \ldots \ldots . . . .112$

4.4 Black boxes on open TRU pad ………….......................................... 13

4.5 Uniform heat distribution

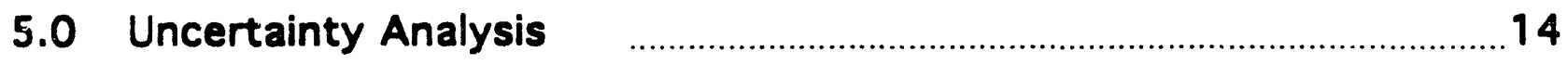

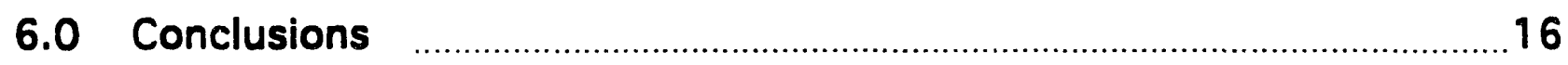

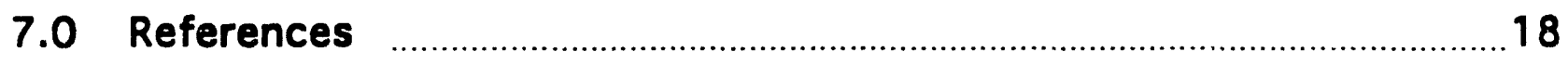

8.0 Figures 20

9.0 Attachments; Calculation Sheets 


\subsection{Summary}

Heat loading limits have been established for four storage configurations of TRU wastes. The calculations were performed assuming the worst case scenario whereby all the heat generated within a drum was generated within one "cut" and that this cut was located in the very center of the drum. Poly-boxes containing one HEPA filter were assumed to have a uniform heat generation throughout the filter. The maximum allowable temperatures were based on the materials in the containers. The calculated heat load limits per container (i.e. 55 gallon drum, poly-box, or black box) are summarized in the table below.

\begin{tabular}{c|c|c} 
& Without Anion Resin. & With Anion Resin. \\
\hline $\begin{array}{c}55 \text { Gallon drums in } \\
\text { culvert on an open } \\
\text { TRU pad. }\end{array}$ & $\begin{array}{c}30 \mathrm{Btu} / \mathrm{hr} \\
(8.793 \mathrm{Watts})\end{array}$ & $\begin{array}{c}2.5 \mathrm{Btu} / \mathrm{hr} \\
(0.73 \mathrm{Watts})\end{array}$ \\
\hline 55 Gallon drums on & & $3 \mathrm{Btu} / \mathrm{hr}$ \\
an enclosed TRU pad. & $(8.793 \mathrm{Watts})$ & $(0.879 \mathrm{Watts})$ \\
\hline $\begin{array}{c}\text { Poly-boxes in a } \\
\text { culvert on an open } \\
\text { TRU pad. }\end{array}$ & $\begin{array}{c}(17.58 \mathrm{Btu} / \mathrm{hr} \\
\text { Watts })\end{array}$ & $\begin{array}{c}14 \mathrm{Btu} / \mathrm{hr} \\
(4.1 \mathrm{Watts})\end{array}$ \\
\hline $\begin{array}{c}\text { Black boxes on an } \\
\text { open TRU pad. }\end{array}$ & $22 \mathrm{Btu} / \mathrm{hr}$ & $0.5 \mathrm{Btu} / \mathrm{hr}$ \\
& $(6.448 \mathrm{Watts})$ & $(0.146 \mathrm{Watts})$
\end{tabular}

A comparison between the drum center temperature for a uniform heat load distribution and for the center temperature when the heat load is confined to one cut in the center of the drum is aiso illustrated. This comparison showed that the heat load of a particular drum can be more than doubled by distributing the sources of heat uniformly throughout the container.

\subsection{Introduction}

Job-control TRU waste generated at the Savannah River Site (SRS) is packed in multiple barrier layers of plastic and stored in $\mathbf{5 5}$ gallon drums, carbon-steel black boxes, polyethylene boxes, and casks. The waste generated before 1986 was stored on concrete slabs, referred to as TRU pads, under 2 to 4 feet of earthen cover in the Solid Waste Disposal Facility (SWDF). Safe heat loading limits have previously been calculated for this earthen-covered storage configuration [1]. The waste generated after 1986 has been stored above ground on TRU pads. The above ground storage configurations were investigated in 
this report under the task plan 'Heat Loading Limit Calculation for Storage of Solid Transuranium Wastes' (Task number 93-013-1).

There are four storage configurations for the above-ground storage of solid transuranic wastes that are presented.

- 55 gallon drums in concrete culvert on an open TRU pad. Job-control waste is bagged into a PVC bag and placed into a 5 gallon pail which is lined with a polyethylene bag. The bag is removed from the pail, after assay, and referred to as a "cut". Seven of these cuts are placed into a 55 gallon drum. The 55 gallon drum is lined with both a polyethylene bag and then a polyethylene liner. Each concrete culvert contains a 'otal of 14 drums in two layers of 7 drums per layer. The concrete culvert is stored on an open TRU pad. Details of the "cut", drum, polyethylene liner, and culvert can be found in Ref. $[2,3,4,5$, and 6$]$.

- $\quad 55$ gallon drums on enclosed TRU pad.

These are the same 55 gallon drums and contents as mentioned above. These drums are not placed inside of the concrete culvert but are simply stacked, 2 high, on a TRU pad. One TRU pad may contain 4200 drums. The TRU pad is covered with a free-span portable enclosure that can be built around an existing TRU pad. Details of the enclosure can be found in Ref. [7].

- Poly-boxes in concrete culverts on an open TRU pad.

Poly-boxes are constructed of 1/8" thick cross-linked polyethylene. They are rectangular in shape with an approximate volume of 65 gallons. There is a total of 8 polyboxes placed in a concrete culvert in 2 layers of 4 boxes per layer. Each poly-box contains one HEPA filter [8]. The HEPA filter was assumed to have a uniform heat generation throughout the filter.

- Black boxes on an open TRU pad.

Black boxes are large carbon steel boxes $\left(12^{\prime} \times 18^{\prime} \times 7^{\prime}\right)$ that are placed on an open TRU pad. The contents of the black boxes are larger items than the drums can hold; such as cabinets, tanks, glove boxes, desks, etc.. Details of the black boxes can be found in Ref. [9].

Safe heat loading limits are defined to prevent the ignition of anion exchange resin, the ignition of paper, the melting of low-density polyethylene, and the melting of high-density polyethylene. A table of limiting temperatures is given below. 


\begin{tabular}{|c|c|c|}
\hline SUBSTANCE [Ref.] & DEGRADATION TEMP. & MELT/FAILURE TEMP. \\
\hline $\begin{array}{c}\text { High-density } \\
\text { polyethylene [10] }\end{array}$ & $\begin{array}{c}109 \pm 24.7^{\circ} \mathrm{C} \\
\left(228.2 \pm 44.46^{\circ} \mathrm{F}\right)\end{array}$ & $\begin{array}{c}123.5 \pm 23.3^{\circ} \mathrm{C} \\
\left(254.3 \pm 41.94^{\circ} \mathrm{F}\right)\end{array}$ \\
\hline $\begin{array}{c}\text { Low-density } \\
\text { polyethylene [10] }\end{array}$ & $\begin{array}{c}82.5 \pm 31.8^{\circ} \mathrm{C} \\
\left(180.5 \pm 57.24^{\circ} \mathrm{F}\right)\end{array}$ & $\begin{array}{c}92.8 \pm 17.7^{\circ} \mathrm{C} \\
\left(199.04 \pm 31.86^{\circ} \mathrm{F}\right)\end{array}$ \\
\hline $\begin{array}{c}\text { Anion resin } \\
\text { decomposition [1] }\end{array}$ & $87.78^{\circ} \mathrm{C}\left(190^{\circ} \mathrm{F}\right)$ & \\
\hline Paper ignition [1] & & $232.2^{\circ} \mathrm{C}\left(450^{\circ} \mathrm{F}\right)$ \\
\hline ALARA [10] & $37^{\circ} \mathrm{C}\left(98.6^{\circ} \mathrm{F}\right)$ & $79^{\circ} \mathrm{C}\left(174.2^{\circ} \mathrm{F}\right)$ \\
\hline PVC [10] & $66^{\circ} \mathrm{C}\left(150.8^{\circ} \mathrm{F}\right)$ & $89.3 \pm 17.9^{\circ} \mathrm{C}$ \\
$\left(192.74 \pm 32.22^{\circ} \mathrm{F}\right)$ \\
\hline
\end{tabular}

The melting temperature of high-density polyethylene corresponds to the melting of the drum liner and the melting temperature of the poly-boxes. The ignition temperature of paper corresponds to a maximum temperature within a cut, as long as the cut does not contain anion resin. The anion resin decomposition temperature corresponds to the maximum temperature within a cut that does contain anion resin. The failure of the polyethylene bag containing one cut corresponds to the melting temperature of low-density polyethylene. The failure temperature of PVC corresponds to the melting of the HEPA filter liner bag. ALARA is packing material used in the black boxes and was not considered in establishing of the heat load limits of the black boxes. ALARA was not used in any of the other storage configurations.

\subsection{Calculation Method}

In this section a description of the assumptions made and the approach used will be discussed. It is important to note that all assumptions made were conservative. Each configuration will be discussed separately. Details of the actual numbers used to yield the results are given in Section 9, "Attachments; Calculation Sheets".

To keep the scope of this task within the guidelines of a "Small Task" (see Ref. [11]) and due to the time-frame constraints the following assumption was made. The heat transfer within the drums and poly-boxes was simplified from the 2-D and 3-D conduction with heat generation problems to a one dimensional conduction with heat generation problem by using a spherical coordinate system. The 
drum, for example, was assumed to be ericompassed by a sphere. The sphere's surface temperature was assumed to be the same temperature as the drum surface would be. This imaginary sphere would result in a higher center temperature than the actual drums center temperature, which makes this simplification very conservative. The hottest any drum can get is when all the heat being generated is evolved by one cut at the very center of this imaginary sphere. This "one cut generation" scenario will be used to establish the heat load limits. The "cut" will also be characterized by a sphere of radius $0.54 \mathrm{ft}$ and located at the center of the drum (or poly-boxes), also modeled by an imagi- ary sphere [12,13]. The total heat generated within one culvert will be assumed to be the product of the heat generated by the hottest drum and the number of drums inside the culvert.

The thermal conductivity of the job-control waste is non-uniform and unknown. Previous calculations have used $0.05 \mathrm{Btu} / \mathrm{hr} / \mathrm{ft} /{ }^{\mathrm{P}} \mathrm{F}$ as the assumed thermal conductivity of the bagged waste [1]. To be thoroughly conservative the calculations will be made for the thermal conductivity of air $\left(0.02 \mathrm{Btu} / \mathrm{hr} / \mathrm{ft} /{ }^{\circ} \mathrm{F}\right)$ and for the same thermal conductivity that was used in previous calculations $(0.05$ $\mathrm{Btu} / \mathrm{hr} / \mathrm{ft} /{ }^{\circ} \mathrm{F}$ ). Conclusions drawn from the results will be made upon the calculations with the thermal conductivity of air since they are the more conservative of the two calculations.

Convective heat transfer is present in every storage configuration under investigation. For example there is convection from the drums to the air under the enclosure or there is convection from the polyboxes to the air inside the culvert and from the air inside the culvert to the culvert walls. Previous calculations have used the following two equations for the vertical and horizontal heat transfer coefficients [1].

$$
\begin{aligned}
& h_{\mathrm{V}}=0.23 *(\Delta \mathrm{T})^{\frac{1}{3}} \\
& \mathrm{~h}_{\mathrm{H}}=0.25 *(\Delta \mathrm{T})^{\frac{1}{3}}
\end{aligned}
$$

These equations are valid for heat transfer from a vertical or horizontal surface into a semi-infinite space. For the packing matrix of either the drums or the poly-boxes inside of the culvert these equations are not totally valid. The center drum in a culvert, for example, with six drums surrounding it offers more resistance to air flow along its vertical surfaces than the same drum would 
without the other six drums surrounding it. The scope of this task did not allow for any detailed analysis of the heat transfer coefficients; therefore, another conservative simplifying assumption had to be made. The heat transfer coefficient was divided by two for any surface that appeared to be in close proximity with another surface.

In every storage configuration under investigation there is an outer surface that is exposed to the atmosphere. This is a significantly different scenario than the under-ground storage of solid transuranium wastes. These outer surfaces are subject to incident solar radiant heat transfer, emmitance of thermal radiation heat transfer, convective heat transfer to the atmosphere, and the generated heat from the waste. The incident solar radiation, just outside the atmosphere, is reported to be $442.8 \mathrm{Btu} / \mathrm{hr} / \mathrm{ft}^{2}[14,15]$. An additional $20-40 \%$ is absorbed by the earth's atmosphere, but for this study it was assumed that only $10 \%$ is absorbed by the atmosphere and that $90 \%$ of the $442.8 \mathrm{Btu} / \mathrm{hr} / \mathrm{ft}^{2}$ strikes the surface in question [16].

The amount of thermal radiation and convection leaving the outer surface is dependent upon the air temperature. Once again, in an attempt to be conservative the air temperature was assumed to be $110^{\circ} \mathrm{F}$. This was a reasonable assumption for the worst case air temperature.

The incident solar radiation on a surface and the emitted thermal radiation from a surface are dependent on the surface absorbtivity and emissivity, respectively, of the surface. These properties are not known with any degree of certainty for the three types of exposed surfaces under investigation. This was the primary source of uncertainty for these calculations. A literature search was performed in an attempt to establish these surface properties within a $95 \%$ confidence interval. The discussion of these surface prope:-ies will be given in the "Uncertainty Analysis", Sec. 5.0.

The modes of heat transfer for each of the 4 storage configurations will be discussed next. Details of the analysis can be seen in the calculation sheets in the "Attachments", Sec. 9.0.

3.1 55 gallon drums in concrete culvert on an open TRU pad. Conduction with generation through the cut at the center of the dium. 
- Conduction through the rest of the drum.

- $\quad$ Conveccion from the drum walls to the air inside the culvert.

- Convection from the air inside the culvert to the culvert walis and lid.

- $\quad$ Conduction through the culvert walls and lid.

- Incident solar radiation, emitted thermal radiation, convection to atmosphere, and heat generated from waste at the culvert outer surface.

3.25 gallon drums on enclosed TRU pad.

- $\quad$ Conduction with generation through the cut at the center of the drum.

- $\quad$ Conduction through the rest of the drum.

- Convection from the drum walls to the air inside the enclosure.

- Convection from the air inside the enclosure to the enclosure surface.

- Incident solar radiation, emitted thermal radiation, convection to atmosphere, and heat generated from waste at the enclosure surface.

3.3 Poly-boxes in concrete culvert on an open TRU pad.

- Conduction with generation within the HEPA filter.

- $\quad$ Conduction through the rest of the box.

- $\quad$ Convection from the box walls to thr; air inside the culvert.

- Convection from the air inside the culvert to the culvert walls and lid.

- Conduction through the culvert walls and lid.

- Incident solar radiation, emitted thermal radiation, convection to atmosphere, and heat generated from waste at the culvert outer surface.

\subsection{Black boxes on an open TRU pad.}

- Conduction with generation through the cut at the center of the box.

- $\quad$ Conduction through the rest of the box.

- Incident solar radiation, emitted thermal radiation, convection to atmosphere, and heat generated firom waste at the black box outer surface.

\subsection{Results}

The results will be presented for each configuration separately. Graphs will be presented where each surface of interest is plotted 
versus the heat generated per container. Also plotted will be error bars for the surface temperatures. The heat loading limits will be based on the most conservative assumed thermal conductivity of the waste of $0.02 \mathrm{Btu} / \mathrm{hr} / \mathrm{ft} /{ }^{\circ} \mathrm{F}$.

4.1 55 gallon drums in concrete culvert on an open TRU pad. The results from the calculations for the $\mathbf{5 5}$ gallon drums inside a concrete culvert on an open TRU pad are shown in Fig. 1. The shaded areas represent the constraints of the melting temperature of highdensity polyethylene, from $212.4^{\circ} \mathrm{F}$ to $296^{\circ} \mathrm{F}$, and for the ignition temperature of paper, above $450^{\circ} \mathrm{F}$. The uncertainty of all the surface temperature measurements is $\pm 7.5^{\circ} \mathrm{F}$. The surface temperature uncertainty will be discussed in detail in the "Uncertainty Analysis" Sec. 5.0. The results in Fig. 1 represent the worst case scenario where all the heat generated within the drum is generated within one "cut" at the center of the drum. It will be shown laier by comparison with a uniform heat generation scenario that the "one cut generation" assumption yields the hottest internal drum temperature.

The three temperature curves of interest, in Fig. 1, are the drum surface temperature, the temperature at the cut boundary, and the center of the cut temperature (or center of drum temperature).

- The drum surface temperature is constrained by the lowest melt/failure temperature of the high-density polyethylene liner. Figure 1 illustrates that even at $100 \mathrm{Btu} / \mathrm{hr}$ (29.3 Watts) the drum surface will not get hot enough to melt the line:

- The center of cut temperature is constrained by the anion resin decomposition temperature in the presence of anion lesin, and the ignition temperature of paper when anion resin is not present. As a reminder, the anion resin decomposition temperature is $190^{\circ} \mathrm{F}$. In the presence of anion resin the heat load per drum in the culvert is only about $2.5 \mathrm{Btu} / \mathrm{hr}(0.73 \mathrm{Watts})$. When anion resin is it present the heat load jumps to about $30 \mathrm{Btu} / \mathrm{hr}$ ( 8.793 Watts).

- The temperature at the cut boundary was not considered a constraint in the previous calculations but is mentioned here for completeness. The bag containing the cut (cut boundary) will melt at a heat load of about $10 \mathrm{Btu} / \mathrm{hr}$ (2.93 Watts). This bag melting may not be of ary concern as long as the drum liner does not melt and there is no ignition within the drum.

The constraint of primary concern in this configuration is the ignition temperature at the center of the cut (or drum). The heat 
load limit for this configuration is $30 \mathrm{Btu} / \mathrm{hr}$ ( 8.793 Watts) per drum when anion resin is not present and $2.5 \mathrm{Btu} / \mathrm{hr}(0.73$ Watts) when anion resin is present.

4.2 55 gallon drums stacked on an enclosed TRU pad.

The results from the calculations for the 55 gallon drums stacked on an enclosed TRU pad are shown in Fig. 2. The shaded areas represent the constraints of the melting temperature of high-density polyethylene, from $212.4^{\circ} \mathrm{F}$ to $296^{\circ} \mathrm{F}$, and for the ignition temperature of paper, above $450^{\circ} \mathrm{F}$. The uncertainty of all the surface temperature measurements is $\pm 20^{\circ} \mathrm{F}$. The surface temperature uncertainty will be discussed in detail in the "Uncertainty Analysis" Sec. 5.0. The results in Fig. 2 represent the worst case scenario where all the heat generated within the drum is generated within one "cut" at the center of the drum.

The thiree temperature curves of interest, in Fig. 2, are the drum surface temperature, the temperature at the cut boundary, and the center of the cut temperature (or center of drum temperature).

- The drum surface temperature is constrained by the lowest melt/failure temperature of the high-density polyethylene liner. Figure 2 illustrates that even at $80 \mathrm{Btu} / \mathrm{hr}(23.45$ Watts) the drum surface will not get hot enough to melt the liner.

- The center of cut temperature is constrained by the anion resin decomposition temperature, in the presence of anion resin, and the ignition temperature of paper, when anion resin is not present. As a reminder, the anion resin decomposition temperature is $190^{\circ} \mathrm{F}$. In the presence of anion resin the heat load per drum in the culvert is only about $3 \mathrm{Btu} / \mathrm{hr}$ (0.879 Watts). When anion resin is not present the heat load jumps to about 30 Biu/hr (8.793 Watts).

- The temperature at the cut boundary was not considered a constraint in the previous calculations but is mentioned here for completeness. The bag containing the cut (cut boundary) will melt at a heat load of about $6 \mathrm{Btu} / \mathrm{hr}$ ( $1758 \mathrm{Watts})$. This bag melting may not be of any concern as long as the drum liner does not melt and there is no ignition within the drum.

The constraint of primary concern in this configuration is the ignition temperature at the center of the cut (or drum). The heat load limit for this configuration is $30 \mathrm{Btu} / \mathrm{hr}$ ( 8.793 Watts) per drum when anion resin is not present and $3 \mathrm{Btu} / \mathrm{hr}$ (0.879 Watts) when anion resin is present. 
4.3 Poly-boxes in concrete culverts on an open TRU pad.

The results from the calculations for the poly-boxes inside a concrete culvert on an open TRU pad are shown in Fig. 3 . The shaded areas represent the constraints of the melting temperature of highdensity polyethylene from $212.4^{\circ} \mathrm{F}$ to $296^{\circ} \mathrm{F}$, the melting temperature of PVC from $160^{\circ} \mathrm{F}$ to $225^{\circ} \mathrm{F}$, and for the ignition temperature of paper above $450^{\circ} \mathrm{F}$. The uncertainty of all the surface temperature measurements is $\pm 7.5^{\circ} \mathrm{F}$. The surface temperature uncertainty will be discussed in detail in the "Uncertainty Analysis" Sec. 5.0. The results in Fig. 4 represent the worst case scenario where all the heat generated within the polybox is uniformly generated within the HEPA filter. Each poly-box contains one HEPA filter surrounded by two PVC bags [8].

The three temperature curves of interest, in Fig. 3, are the poly-box surface temperature, the temperature at the filter boundary, and the center of the filter temperature (or center of poly-box temperature).

- The box surface temperature is constrained by the lowest melt/failure temperature of the high-density poly-box. Figure 3 illustrates that even at $100 \mathrm{Btu} / \mathrm{hr}$ (29.3 Watts) the box surface will not get hot enough to melt the poly-box itself.

- The center of filter temperature is constrained by the anion resin decomposition temperature, in the presence of anion resin, and the ignition temperature of paper, when anion resin is not present. As a reminder, the anion resin decomposition temperature is $190^{\circ} \mathrm{F}$. In the presence of anion resin the heat load per poly-box in the culvert is only about $14 \mathrm{Btu} / \mathrm{hr}(4.1$ Watts). When anion resin is not present the heat load jumps to abcut $130 \mathrm{Btu} / \mathrm{hr}$ (38.09 Watts).

- The temperature at the filter bag was not considered a constraint in the previous calculations but is mentioned here for completeness. The bag containing the HEPA filter will melt at a heat load of about $6 \mathrm{Btu} / \mathrm{hr}$ (1.758 Watts). This bag melting may not be of any concern as long as the poly-box does not melt and there is no ignition within the poly-box.

The constraint of primary concern in this configuration is the failure temperature of the high-density polyethylene poly-box in conjunction with the center of the filter temperature in the presence of anion resin. The heat load limit for this configuration is $60 \mathrm{Btu} / \mathrm{hr}$ (17.58 Watts) per box when anion resin is not present. This $60 \mathrm{Btu} / \mathrm{hr}$ limit assumes that there is a possibility of the inner liner bag failing but that the final barrier, the poly-box itself, will 
not fail. The heat load limit reduces to $14 \mathrm{Btu} / \mathrm{hr}(4.1$ Watts) when anion resin is present.

4.4 Black boxes on an open TRU pad.

The contents of the black boxes is varied. A typical black box contents may be a limestone drum cabinet surrounded by bags of miscellaneous wastes [17]. The results presented here assume that all the heat generated within the black box is generated within one of the bags of miscellaneous wastes and that this bag is located in the middle of the blar.k box.

The results from the calculations for the black boxes on an open TRU pad are shown in Fig. 4. The shaded areas represent the constraints of the melting temperature of high-density polyethylene, from $212.4^{\circ} \mathrm{F}$ to $296^{\circ} \mathrm{F}$, and for the ignition temperature of paper, above $450^{\circ} \mathrm{F}$. The uncertainty of all the surface temperature measurements is $\pm 15^{\circ} \mathrm{F}$. The surface temperature uncertainty will be discussed in detail in the "Uncertainty Analysis" Sec. 5.0. The results in Fig. 4 represent the worst case scenario where all the heat generated within the black box is generated within one "cut" at the center of the box.

The two temperature curves of interest, in Fig. 4 , are the temperature at the cut boundary and the center of the cut temperature (or center of box temperature).

- The center of cut temperature is constrained by the anion resin decomposition temperature, in the presence of anion resin, and the ignition temperature of paper, when anion resin is not present. As a reminder, the anion resin decomposition temperature is $190^{\circ} \mathrm{F}$. In the presence of anion resin the heat load for the black box is $0.5 \mathrm{Btu} / \mathrm{hr}(0.146 \mathrm{Watts})$. When anion resin is not present the heat load jumps to about $22 \mathrm{Btu} / \mathrm{hr}(6.448$ Watts).

- The temperature at the cut boundary was not considered a constraint in the previous calculations but is mentioned here for completeness. The bag containing the cut (cut boundary) will melt at a heat load of about 2 Btu/hr ( 0.586 Watts). This bag melting may not be of any concern as long as there is no ignition within the box.

The constraint of primary concern in this configuration is the ignition temperature at the center of the cut (or box). The heat load limit for this configuration is $22 \mathrm{Btu} / \mathrm{hr}$ (6.448 Watts) per black box 
when anion resin is not present and $0.5 \mathrm{Btu} / \mathrm{hr}(0.146$ Watts) when anion resin is present.

4.5 Uniform heat distribution.

All the graphs presented in Figs. 1 to 4 present data with the assumption that all the heat generated has been generated in one cut at the center of the drum (or poly-box). It was mentioned that this "one cut generation" assumption was the worst case scenario for the maximum temperature within a drum (or poly-box). Figure 5 illustrates the difference in the temperature at the center of the drum for a uniform heat load distribution and for the "one cut generation". This illustrates that a higher heat load per drum can be attained by dispersing the heat source over all the cuts within the drum. The constraining criteria then changes from the ignition of paper at the drum center to the melting of the drum liner at a heat load in excess of $100 \mathrm{Btu} / \mathrm{hr}$ (29.3 Watts) per drum.

\subsection{Uncertainty analysis.}

In all four storage configurations under investigation the worst case scenario was assumed. The temperature increases within the waste container (drum or poly-box) was based on the thermal conductivity of air to yield a conservatively high temperature at the center of the waste container. The uncertainty in the calculations comes from the lack of knowledge about the thermal radiation surface properties of the three external surfaces under investigation. These three external surfaces are the concrete culverts, the enclosure, and the black boxes (carbon black steel).

A literature search was done to obtain values of the emissivity and solar absorbtivity of the three external surfaces. In the literature, something resembling the surface in question had to be assumed to have similar surface properties; for example, the black carbon steel was approximated as flat black paint. The results of the literature search are given in the table below.

\begin{tabular}{l|l|l|l|}
\cline { 2 - 4 } \multicolumn{1}{c|}{} & & $\varepsilon$ & $\alpha_{s}$ \\
\hline $\begin{array}{l}\text { Black carbon } \\
\text { steel }\end{array}$ & $\begin{array}{l}\text { Carbon flame } \\
\text { spray [18] }\end{array}$ & & .68 \\
\hline & Black paint [15] & $.96-.98$ & \\
\cline { 2 - 4 } & $\begin{array}{l}\mathrm{ACl}-\mathrm{HW} \\
(6 \mathrm{ONi}, 12 \mathrm{Cr})[19]\end{array}$ & $.89-.82$ & \\
\hline
\end{tabular}




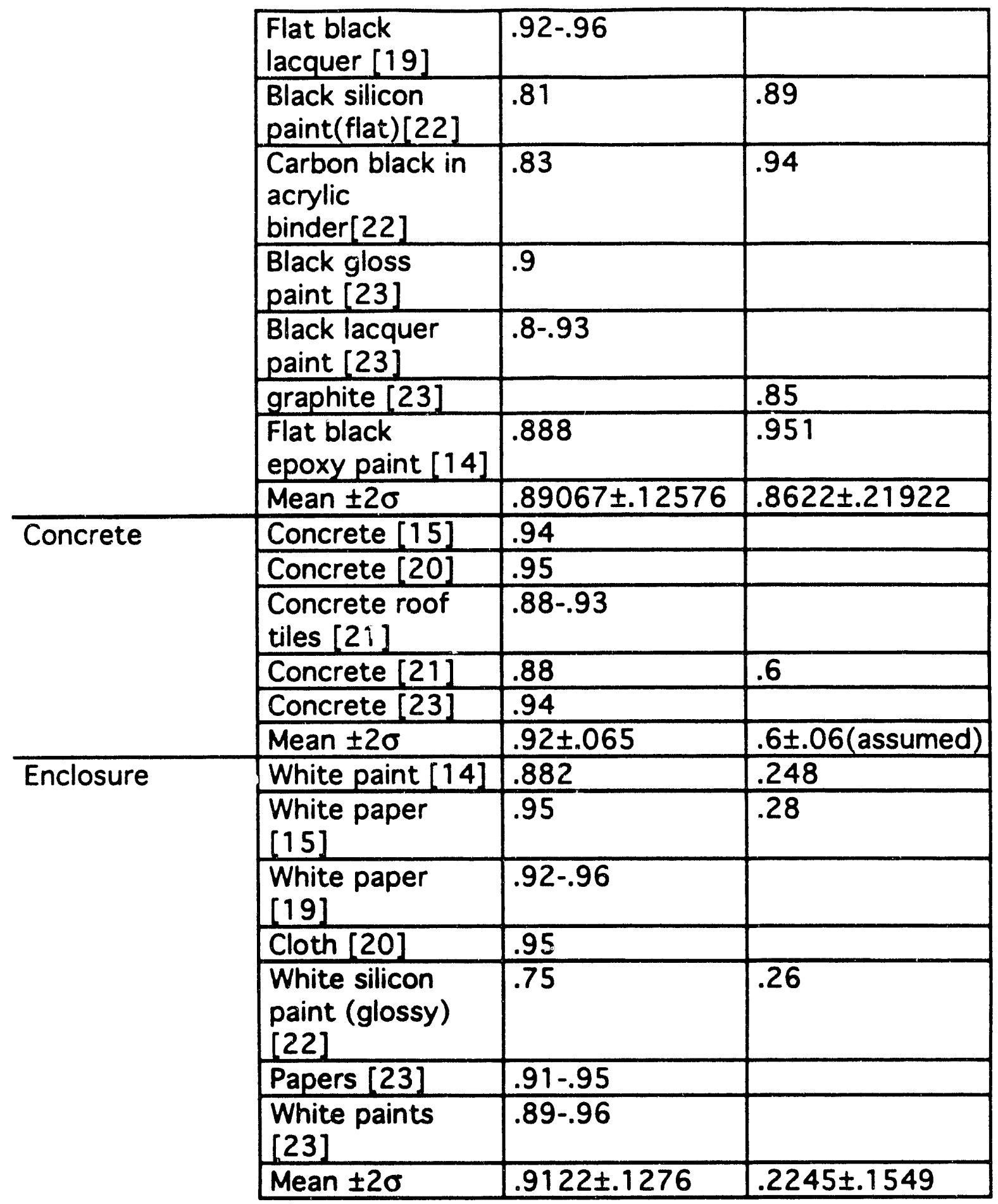

The mean values for the emissivity and absorbtivity were obtained and the $95 \%$ cunfidence interval of $2 \sigma$ was also obtained. The surface temperatures were evaluated at the two extreme cases of $\varepsilon+2 \sigma, \alpha-2 \sigma$ and $\varepsilon-2 \sigma, \alpha+2 \sigma$. The difference between these two extreme 
surface temperatures were used to establish the uncertainty of the surfac $=$ temperatures that is shown on the graphs of Figs. 1-4. The uncertainty of the surface temperatures is independent of the heat load applied from inside the container, but is related solely to the uncertainty of the thermal radiation surface properties. The uncertainty of the external surface temperature propagates to every surface and boundary temperature inside that surface. To surnmarize, for the four external surfaces under investigation the uncertainty of any temperature related to that storage configuration is given in the table below.

\begin{tabular}{|l|l|}
\hline Storage configuration & $\begin{array}{l}\text { Temp. } \\
\text { uncertainties }\end{array}$ \\
\hline $\begin{array}{c}55 \text { gallon drums in concrete culvert on an open } \\
\text { TRU pad }\end{array}$ & $\pm 7.5^{\circ} \mathrm{F}$ \\
\hline 55 gallon drums stacked on an enclosed TRU pad & $\pm 20^{\circ} \mathrm{F}$ \\
\hline $\begin{array}{c}\text { Poly-boxes in concrete culverts on an open TRU } \\
\text { pad }\end{array}$ & $\pm 7.5^{\circ} \mathrm{F}$ \\
\hline Black boxes on an open TRU pad & $\pm 15^{\circ} \mathrm{F}$ \\
\hline
\end{tabular}

\subsection{Conclusions}

Heat loading limits have been established for four storage configurations under the Small Task "Heat Loading Limits Calculation for Storage of Solid Transuranium Wastes", task number 93-013-1. The calculations were performed assuming the worst case scenario where all the heat was generated within one "cut" and that this cut was located in the very center of the drum, or poly-box. The largest uncertainty for the temperature calculations was $\pm 20^{\circ} \mathrm{F}$ in addition to all the conservative assumptions made. The heat load limits per container (i.e. $\mathbf{5 5}$ gallon drum, poly-box, or black box) are summarized in the table given in the "Summary", Sec. 1.0.

The concrete culvert storage configurations yielded the highest heat loads of all the configurations ( $30 \mathrm{Btu} / \mathrm{hr}(8.793$ Watts) per drum). The thermal radiation properties of the concrete maintains a low external surface temperature. A transient analysis would yield an even greater heat load capacity due to the large thermal mass of the concrete culvert. A transient analysis was beyond the scope of this task but could be performed in the future if increased heat loads are anticipated. 
A ccmparison between the drum center temperature for a uniform heat load distribution and for the center temperature when the heat load is confined to one cut in the center of the drum is also illustrated. This comparison showed that the heat load of a particular container can be more than doubled by distributing the sources of heat uniformly throughout the container. 


\subsection{References}

1. B.G. Clontz, "Nuclear Safety and Heat Load Limits for Above-Grade Storage of Solid Transuranium Wastes", Separations Technology Dept., DPSPU 77-11-24.

2. M.L. Meyer and J.R. Shappell, "Nuclear Safety and Heat Loading Limit Calculations for Above-Ground Storage of Solid Transuranium Wastes", WSRC Inter-Office Memo, SRT-WHM-93-016.

3. J.A. Caudill, "Procurement Specification for 55 Gallon Painted Steel Drum", M-SPS-G-00002, Rev. 2, Savannah River Site, Aiken, SC 29808, March 18, 1992.

4. Quotation Submittal by Kenneth D. Gough to WSRC Bid Control Office, Feb. 24, 1992.

5. J.A. Caudill, "Procurement Specification for 90 Mil Polyethylene Liner", WMPMT-00591, Rev. 0, Savannah River Site, Aiken, SC 29808, NOV. 26, 1991. WMWE Drawing No. MM2 E 0002, Rev. 0.

6. J.A. Caudill, "Procurement Specification for TRU Waste Concrete Storage Containers", NMP-WMG-91250, Rev. 0, Savannah River Site, Aiken, SC 29808, Aug. 10, 1991. Drawing No. S5-2-9097, Rev. 8.

7. J.R. Shappell, "Specification for Procuremient of TRU Pad Structural Enclosure System", OPS-WMT-900495, Rev. 3, Savannah River Site, Aiken, SC 29808, May 25, 1990.

8. T.A. Reilly, Memorandom to J.R. Shappell, "Storage of HEPA Filters in Polyethylene Boxes inside of Concrete Culverts", July 14, 1988.

9. K.C. Traven, "Specification for Burial Boxes", C-SPP-F-00029, Rev. 1A, Savannah River Site, Aiken, SC 29808, Oct. 7, 1992, Drawing No. W734050 Rev. 20A, W734049 Rev. 34A.

10. M.L. Meyer, Westinghouse Savannah River Company Notebook, WSRCNB-90-299, pp. 85,86, 104.

11. 1Q-34, "Nuclear Reactor Technology and Scientific Computations Department Quality Assurance Manual (U) ", Westinghouse Savannah River Company, Aiken, SC 29808, Jan. 1, 1991. 
12. D.T. Hobbs, Westinghouse Savannah River Company Notebook, WSRCNB-90-351, pp. 151.

13. M.L. Meyer, Westinghouse Savannah River Company Notebook, WSRCNB-90-299, pp. 87.

14. A.J. Chapman, "Heat Transfer Fourth Edition", Macmillan Publ. Co., New York, Collier Macmillan Publishers, London, 1984.

15. R. Siegel and J.R. Howell, "Thermal Radiation Heat Transfer Second Edition", Hemisphere Publishing Corp., McGraw-Hill Book Co., 1981.

16. M.N. Saha and B.N. Srivastava, "A Treatise on Heat Third Edition", The Indian Press, Ltd., Allahabad and Calcutta, 1950.

17. M.L. Meyer, Westinghouse Savannah River Company Notebook, WSRCNB-90-299, pp. 79, 80.

18. Thermophysical Properties of Matter Vol. 9, Thermal Radiation Properties, Coatings, IFI/Plenum, NY-Washingtion, 1972.

19. Standard Handbook for Mechanical Engineers, Seventh Edition, T. Baumeister, Editor, (L.S. Marks, Editor, 1916-1951), McGraw-Hill Book Company, 1967, pp. 4-111.

20. OMEGA Engineering Inc., OS81, OS82, OS83 Operator's Manual, Appendix A, Emissivity Table, pp. 48, 49.

21. F.P. Incropera and D.P. DeWitt, "Fundamentals of Heat Transfer", John Wiley \& Sons Publ., 1981, pp. 787-790.

22. W.M. Rohsenow, J.P. Hartnett, and E.N. Ganic, "Handbook of Heat Transfer Fundamentals, Second Edition", McGraw-Hill Book Company, 1985, pp. 4-27, 14-20,34.

23. E.M. Sparrow and R.D. Cess, "Radiation Heat Transfer, Augmented Edition", Hemisphere Publ. Corp., 1978, pp. 45-51. 
WSRC-TR-93-174, Rev. 0

\subsection{Figures}

DRUMS INSIDE CULVERT ( $\left.k=0.02 \mathrm{Btu} / \mathrm{h} / \mathrm{ft} /{ }^{\circ} \mathrm{F}\right)$

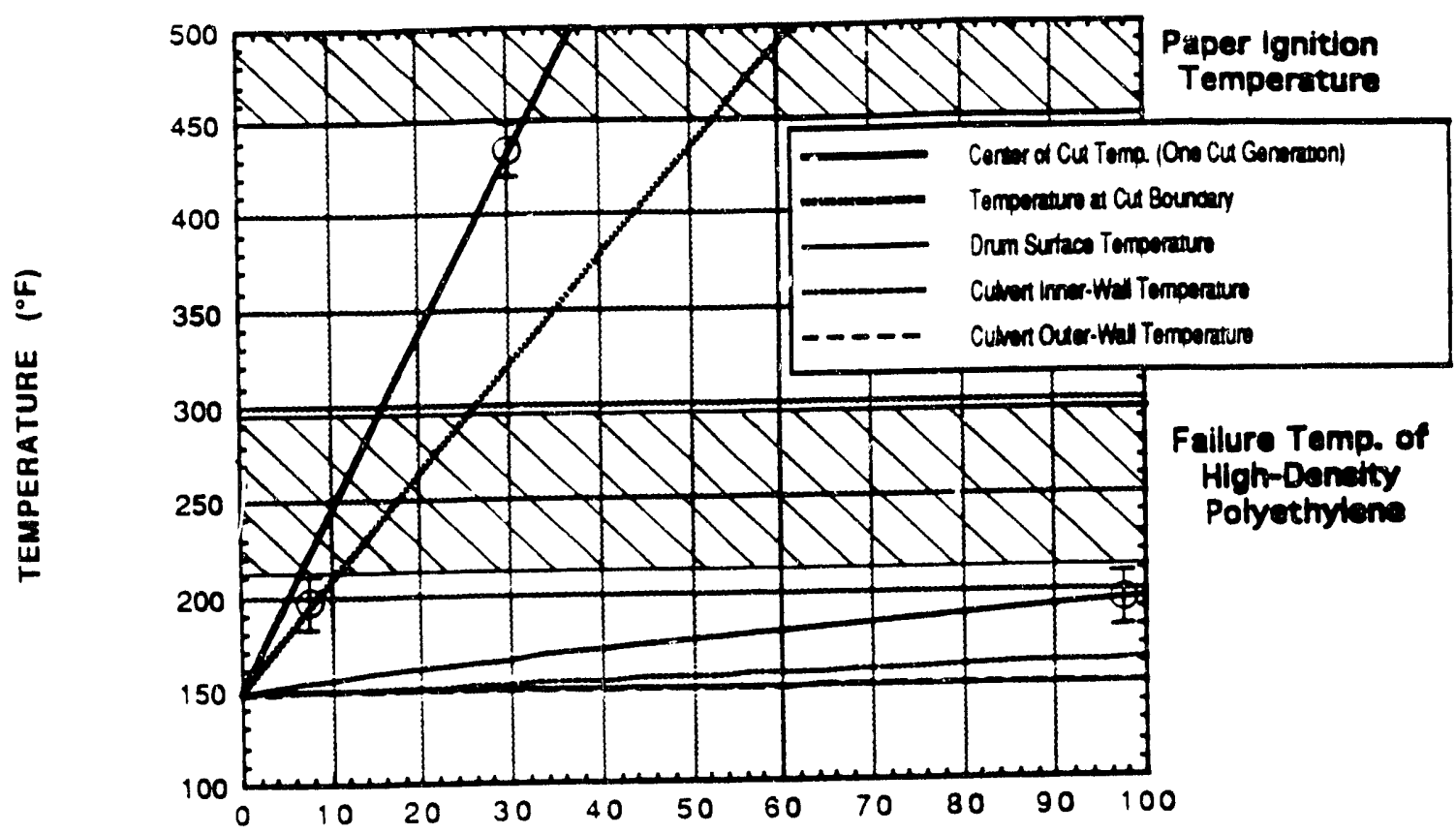

q (BTU/Hr)

DRUMS INSIDE CULVERT ( $\left.k=0.05 \mathrm{Btu} / \mathrm{h} / \mathrm{ft} /{ }^{\circ} \mathrm{F}\right)$

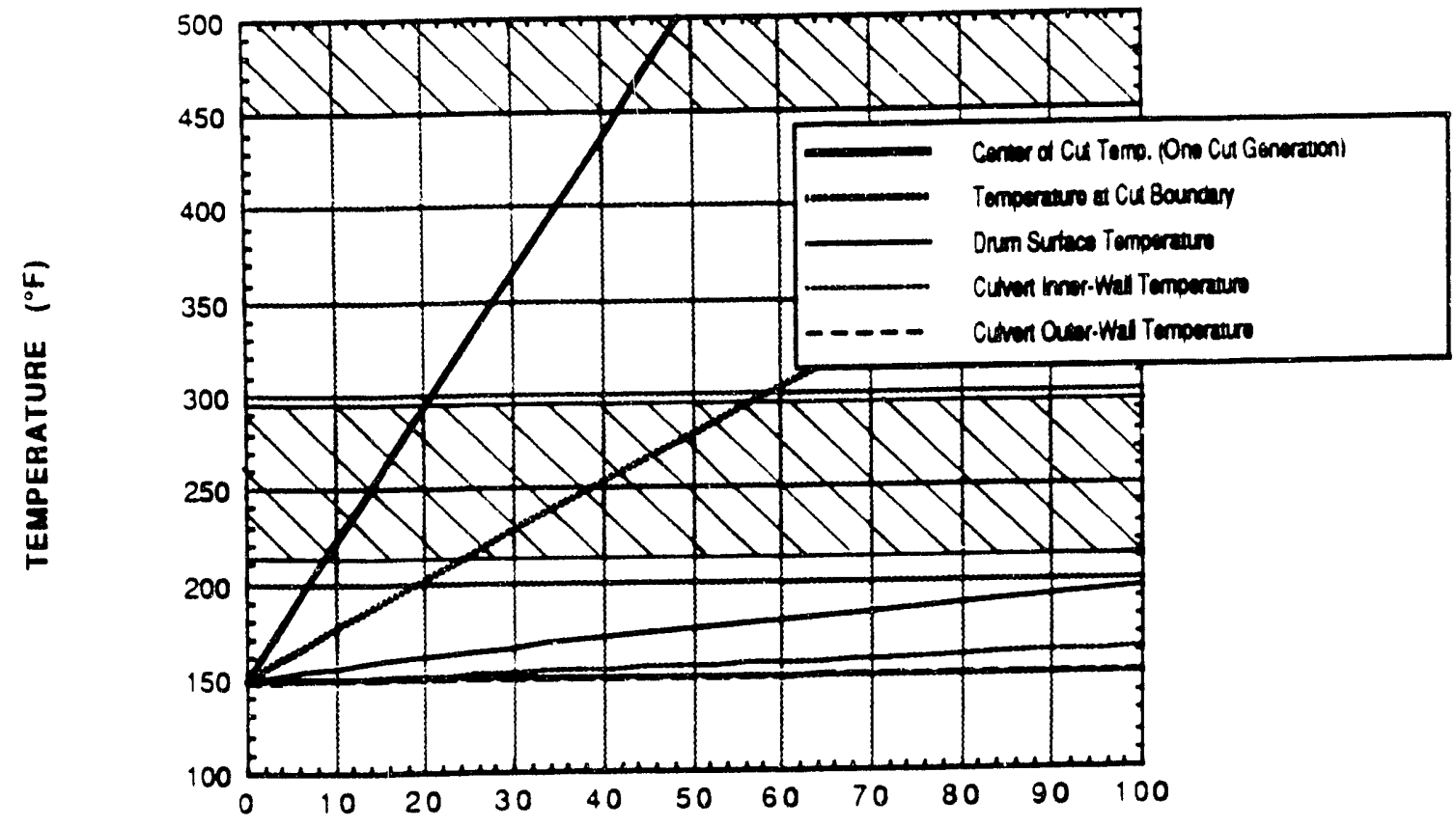

Figure 1

9 (BTU/Hr) 


\section{DRUMS UNDER ENCLOSURE ( $\left.k=0.02 \mathrm{Btu} / \mathrm{h} / \mathrm{ft} /{ }^{\circ} \mathrm{F}\right)$}

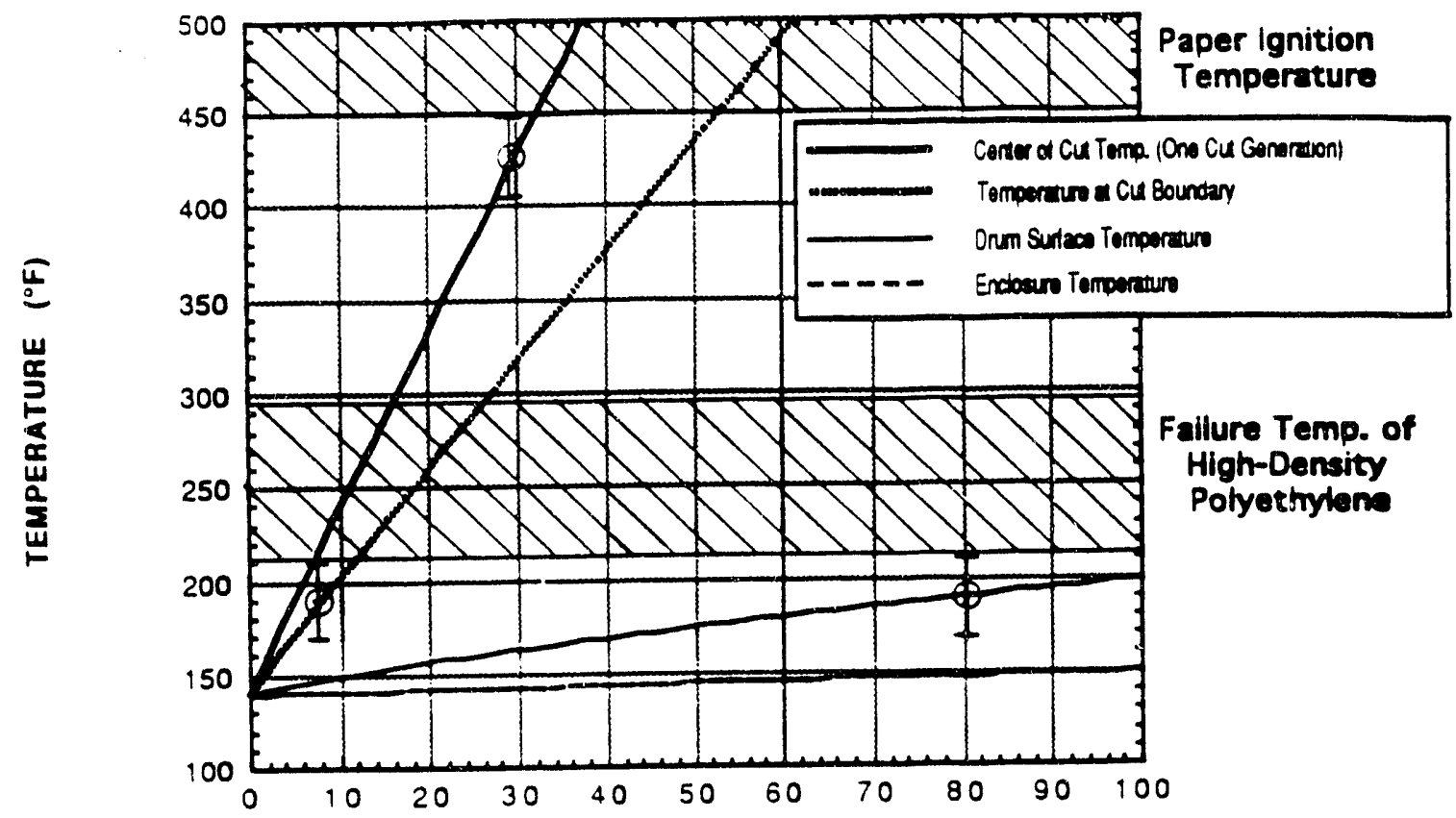

q (BTU/Hr)

DRUMS UNDER ENCLOSURE ( $\left.k=0.05 \mathrm{Btu} / \mathrm{h} / \mathrm{ft} /{ }^{\circ} \mathrm{F}\right)$

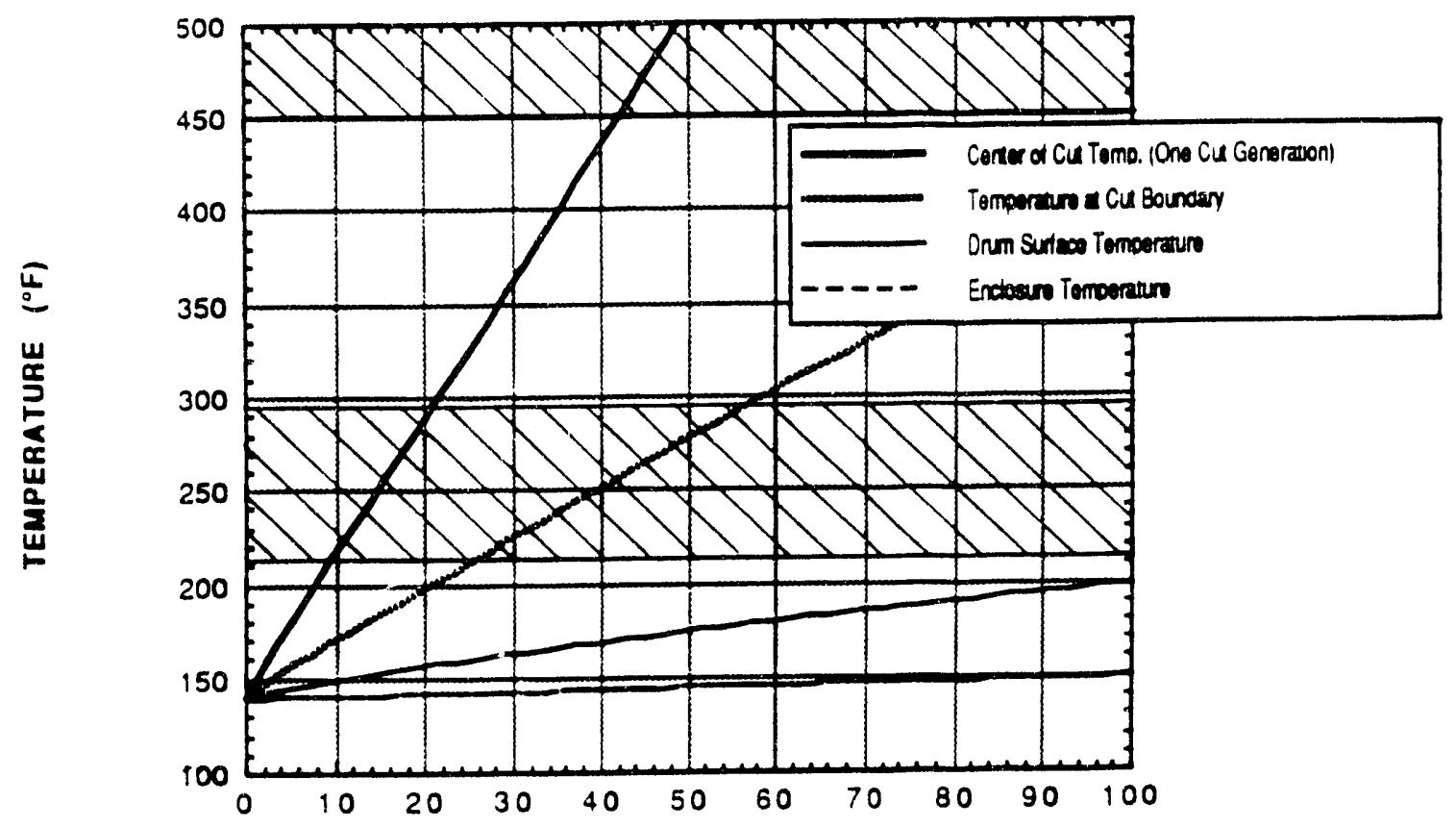

Figure 2 
POLY-BOXES INSILE CULVERT ( $\left.k=0.02 \mathrm{Btu} / \mathrm{h} / \mathrm{ft} /{ }^{\circ} \mathrm{F}\right)$

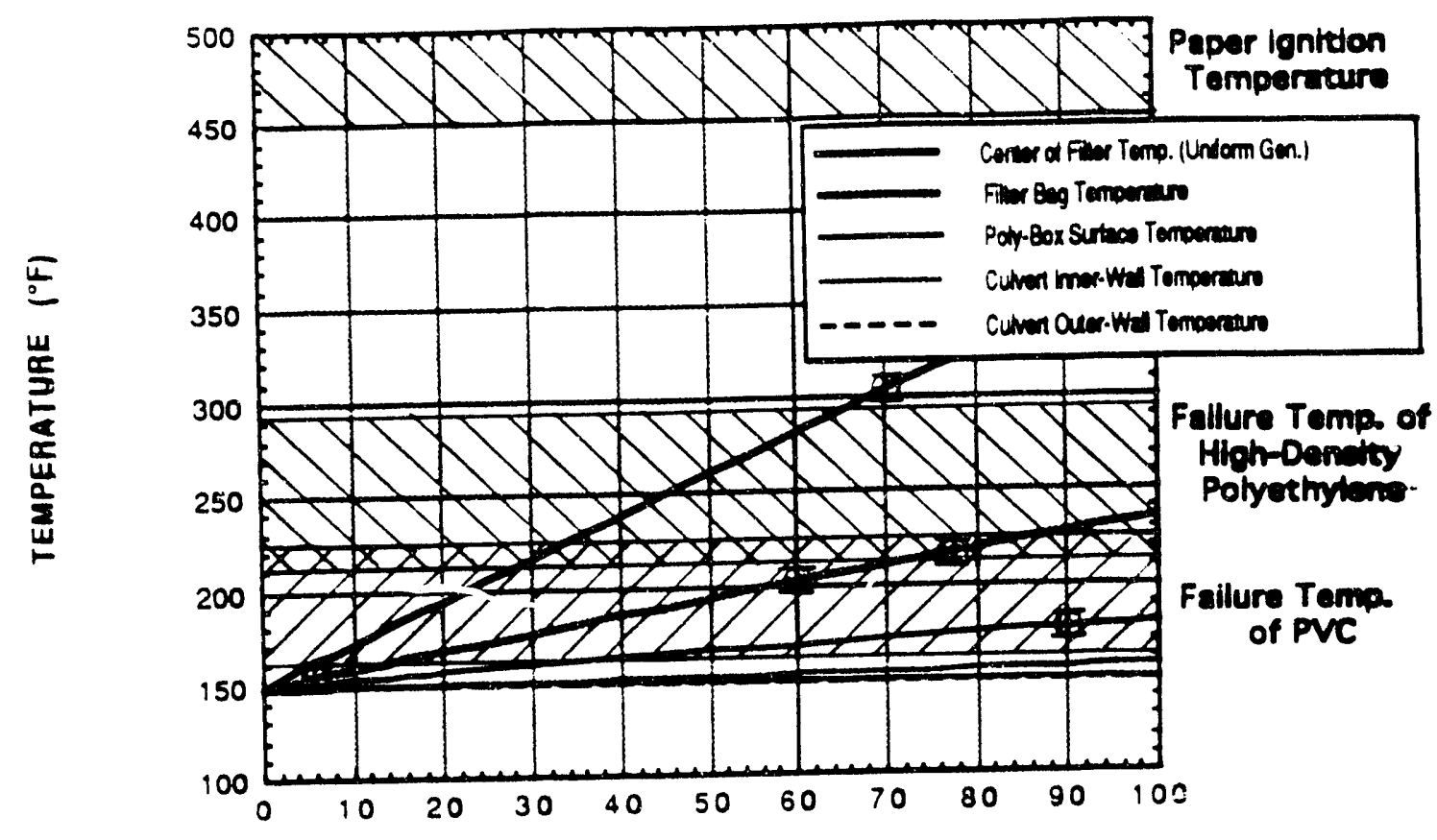

9 (BTU/Hr)

POLY-BOXES INSIDE CULVERT ( $\left.k=0.05 \mathrm{Btu} / \mathrm{h} / \mathrm{ft} /{ }^{\circ} \mathrm{F}\right)$

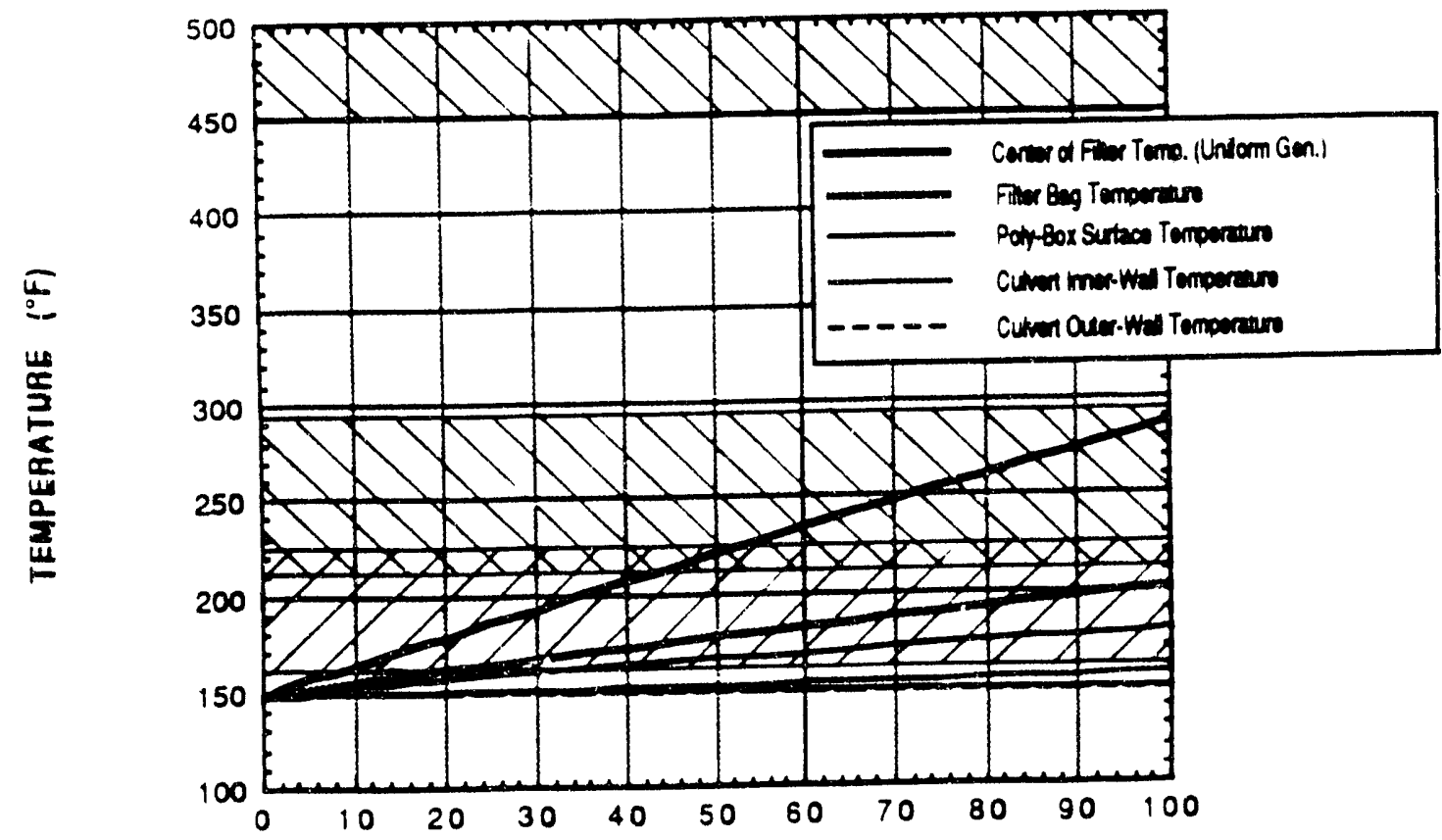

Figure 3

q (BTU/Hr) 
BLACK BOXES ( $\left.k=0.02 \mathrm{Btu} / \mathrm{h} / \mathrm{ft} /{ }^{\circ} \mathrm{F}\right)$

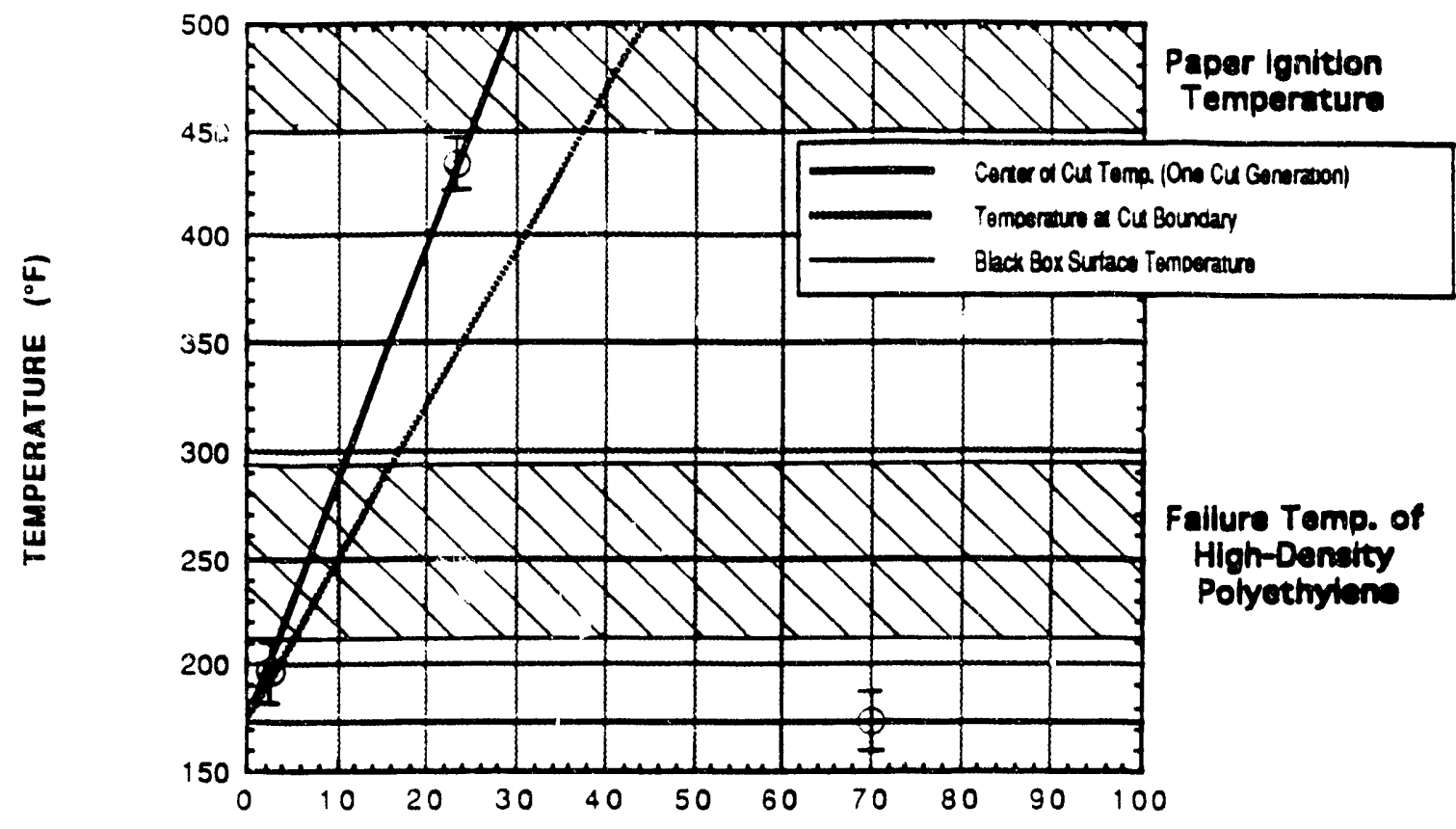

q (BTU/HP)

\section{BLACK BOXES $\left(k=0.05 \mathrm{Btu} / \mathrm{h} / \mathrm{ft} /{ }^{\circ} \mathrm{F}\right)$}

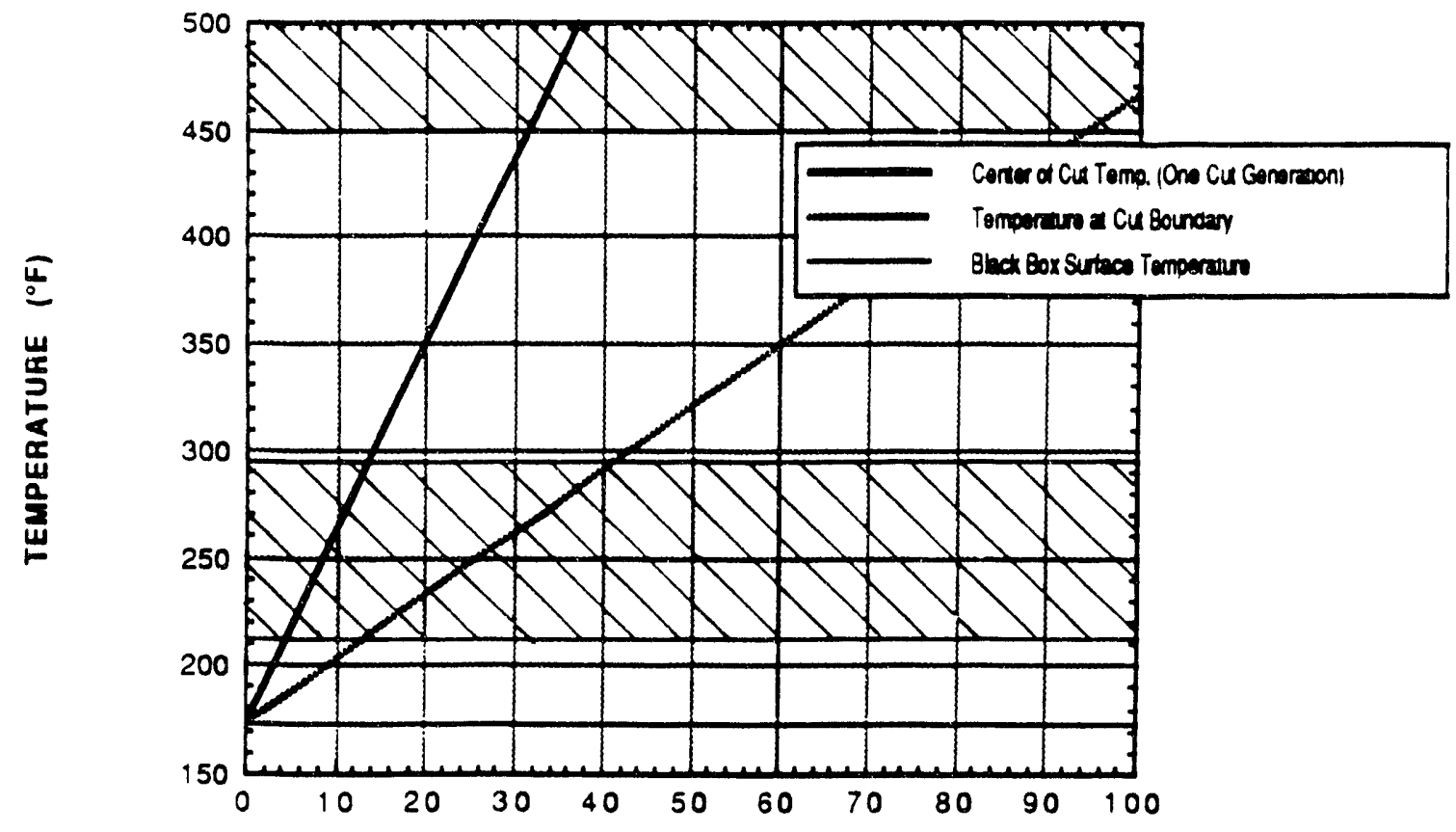

Figure 4

q (BTU/Hr) 


\section{DRUMS INSIDE CULVERT ( $\left.k=0.02 \mathrm{Btu} / \mathrm{h} / \mathrm{ft} /{ }^{\circ} \mathrm{F}\right)$}

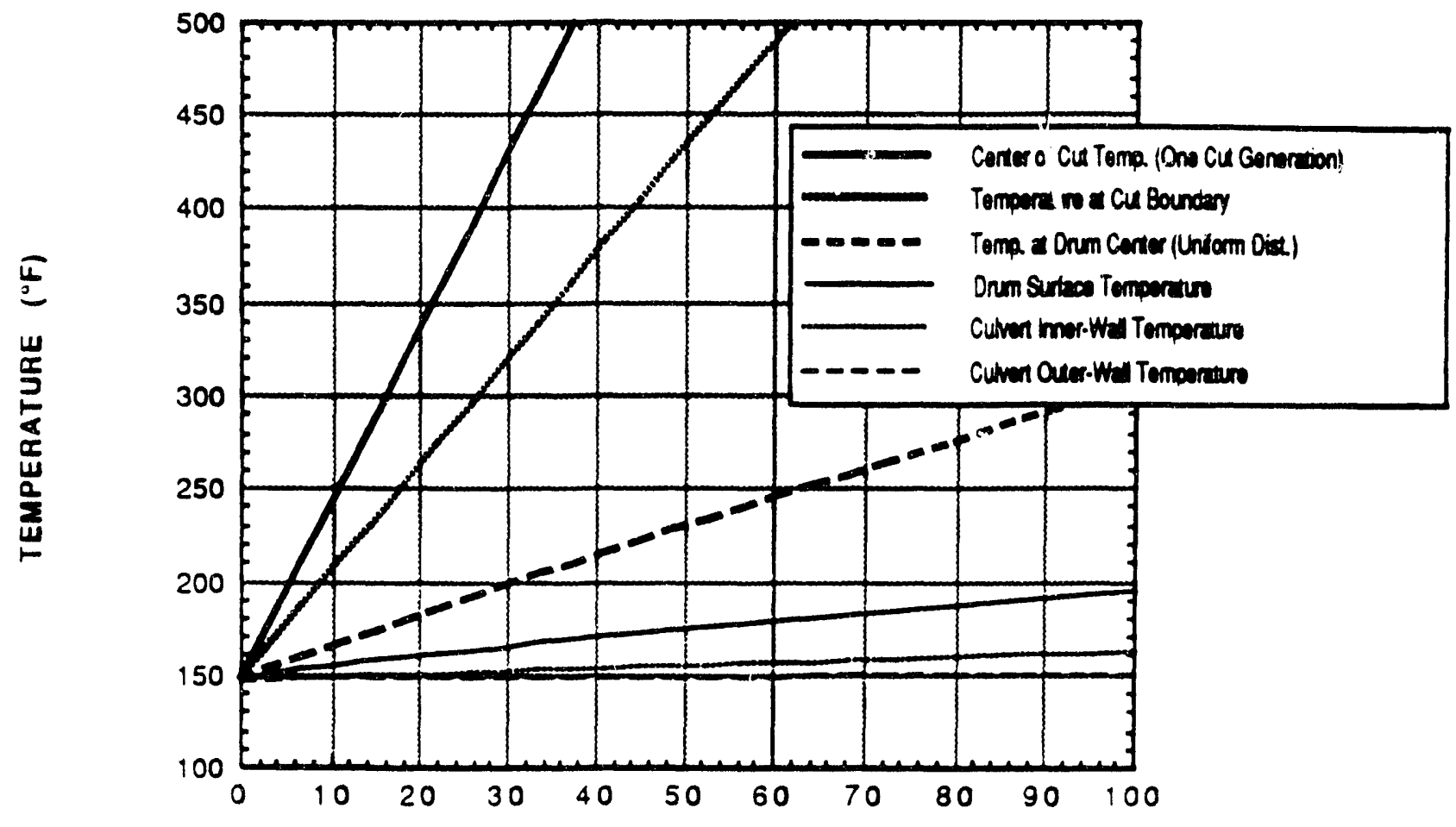

9 (BTU/Hr)

Figure 5 


\subsection{Attachments; Calculation Sheets}

Heat load limit calculations are performed for the following set of conditions:

1) Poly-boxes inside concrete culvert on an open TRU pad.

II) 55 Gallon drums inside concrete culvert on an open TRU pad.

III) 55 Gallon drums (stacked 2 tall) on an enclosed TRU pad.

IV) Black boxes on an open TRU pad.

Microsoft Excel ${ }^{\text {TM }}$ spreadsheets were used to obtain surface temperatures over a range of heat generation. The results were plotted using Cricket $\mathrm{Graph}^{\text {TM }}$ software.

Note: None of the thermal radiation surface properties are given on these calculation sheets.

\section{Evaluation of Surface Areas}

55 Gallon Drums:

$$
\begin{aligned}
& \text { A Horizontal }=\pi r^{2}=\pi(1 \mathrm{ft})^{2}=3.1416 \mathrm{ft}^{2} \\
& A_{\text {Vertical }}=\pi D H=\pi(2 \mathrm{ft})(3 \mathrm{ft})=18.85 \mathrm{ft}^{2}
\end{aligned}
$$

Poly-Boxes:

$$
\begin{aligned}
& A_{\text {Horizontal }}=(16.75 \mathrm{in})(29.25 \mathrm{in})=489.9375 \mathrm{in}^{2}=3.40234 \mathrm{ft}^{2} \\
& A_{\text {Vertical }}=2(16.75 \mathrm{in})(30.75)+2(29.25)(30.75)=2829 \mathrm{in}^{2}=19.646 \\
& \mathrm{ft}^{2}
\end{aligned}
$$

\section{Concrete Culvert:}

Inside:

$$
\begin{aligned}
& A_{\text {Horizontal }}=\pi r^{2}=\pi(3.0833 \mathrm{ft})^{2}=29.87 \mathrm{ft}^{2} \\
& A_{\text {Vertical }}=\pi \mathrm{DH}=2 \pi(3.0833 \mathrm{ft})(6.5 \mathrm{ft})=125.92 \mathrm{ft}^{2}
\end{aligned}
$$


Qutside:

$$
\begin{aligned}
& A_{\text {Horizontal }}=\pi r^{2}=\pi(3.66667 \mathrm{ft})^{2}=42.24 \mathrm{ft}^{2} \\
& A_{\text {Vertical }}=\pi D H=2 \pi(3.66667 \mathrm{ft})(7.66667 \mathrm{ft})=176.63 \mathrm{ft}^{2} \\
& \text { Culvert thickness }=7 \text { in }=0.58333 \mathrm{ft} \\
& \text { Culvert height }=6.5 \mathrm{ft} \\
& \text { Culvert: } \\
& r_{i}=3.08333 \mathrm{ft} \text {. } \\
& r_{0}=3.66666 \mathrm{ft} \text {. }
\end{aligned}
$$

Note: The horizontal area is only for the top of the particular enclosure. It is assumed that the amount of the generated heat that is conducted out the bottom of the enclosure is negligible. This is a conservative assumption. 


\section{Projected Areas}

The projected areas need to be evaluated for the incident solar radiation.

Culvert:
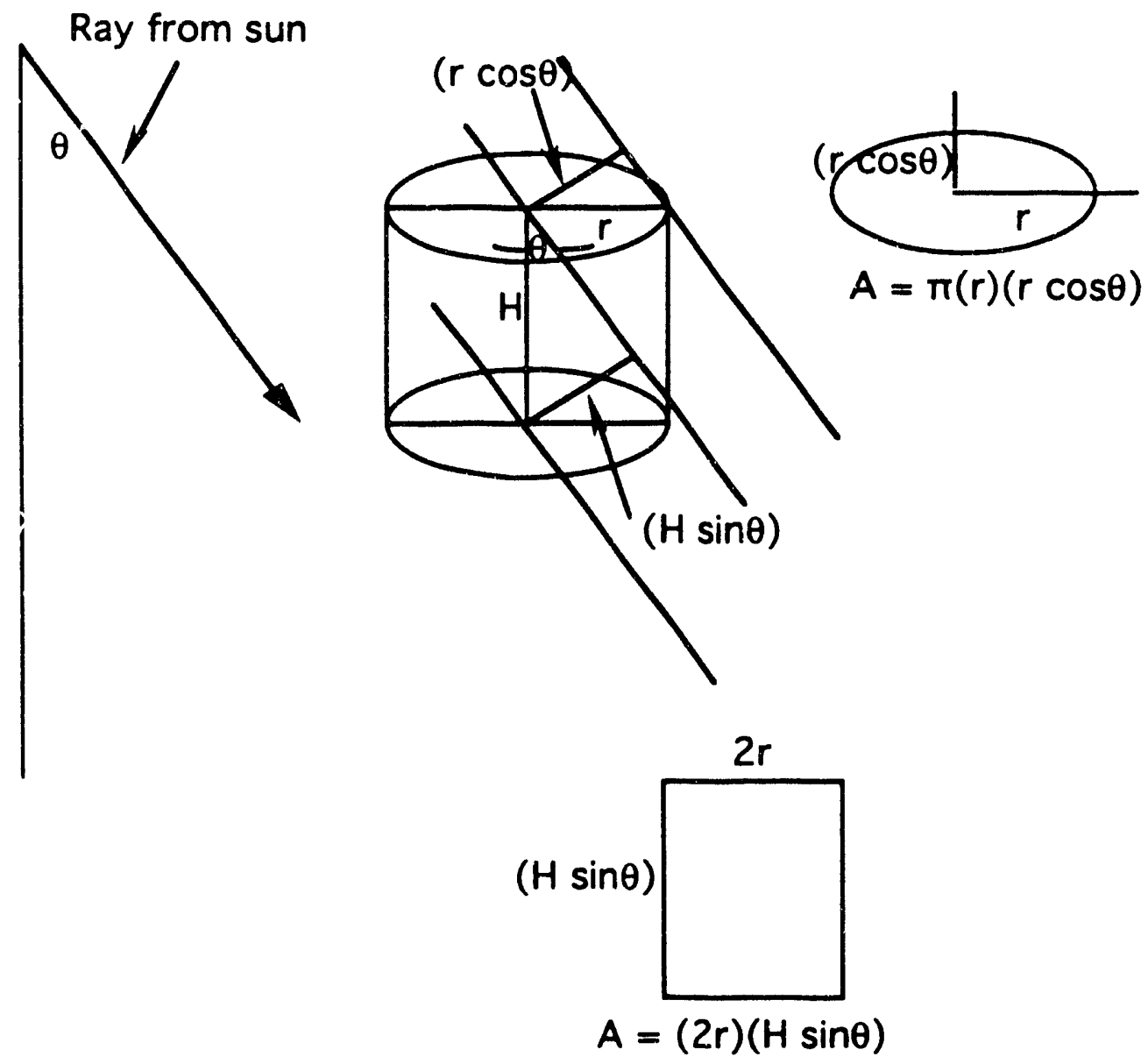

The total projected area is made up of the rectangle and two half ellipses, or the rectangle and an ellipse.

$$
A_{\text {Total }}=A_{\text {Rectangle }}+A_{\text {Ellipse }}=(2 r)(H \sin \theta)+\pi\left(r^{2}\right)(\cos \theta)
$$

The maximum area $\Rightarrow d A / d \theta=0$

or,

$$
\begin{aligned}
& (2 r)(H \cos \theta)-\pi\left(r^{2}\right)(\sin \theta)=0 \\
& \tan \theta=2 H / \pi r
\end{aligned}
$$

Culvert:

$$
\begin{array}{cl}
H=7.66667 & r=3.66667 \\
\text { then, } & \theta=53.084 \mathrm{deg} . \\
\text { and, } & A_{\text {Maximum }}=70.32 \mathrm{ft}^{2} .
\end{array}
$$




\section{Black Boxes:}

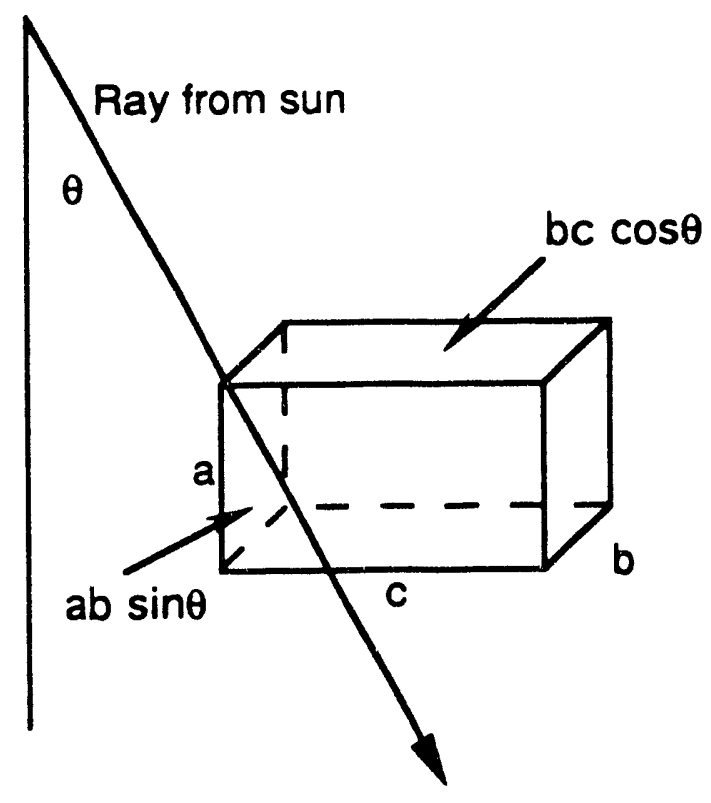

Maximum area with respect to $\theta$ :

$$
\begin{aligned}
& A=(b c)(\cos \theta)+(a b)(\sin \theta) \\
& d A / d \theta=0 \Rightarrow \tan \theta=a / c \quad \text { or } \theta=21 \mathrm{deg} .
\end{aligned}
$$

Next, rotate about an angle perpendicular to the ray.
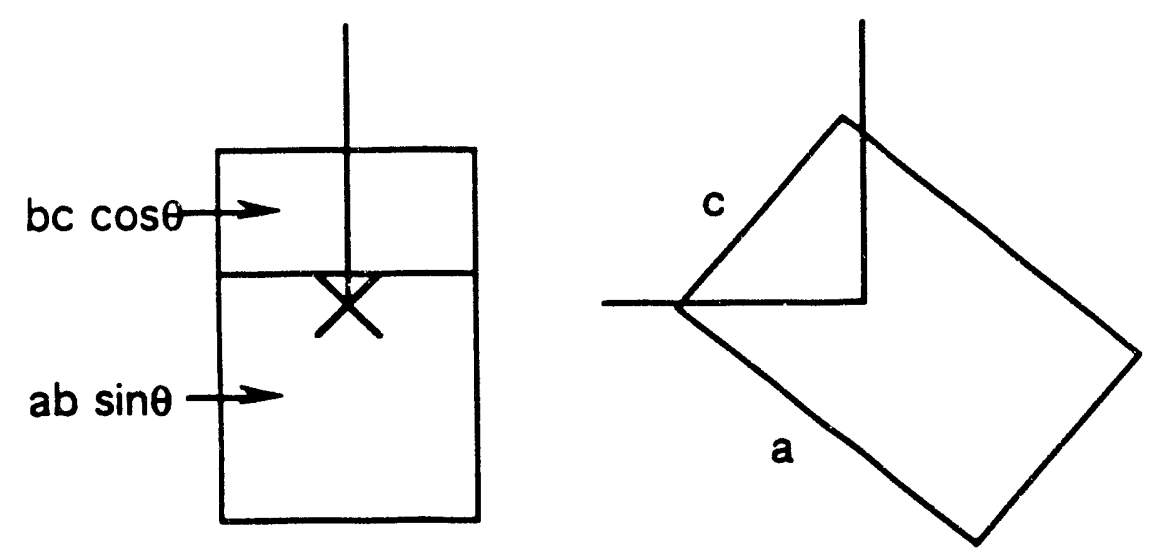

$$
\begin{aligned}
& A=(b c \cos \theta+a b \sin \theta) \cos \phi+a c \sin \phi \\
& \frac{d A}{d \phi}=0=a c \cos \phi-(b c \cos \theta+a b \sin \theta) \sin \phi
\end{aligned}
$$




$$
\tan \phi=\frac{a c+a b \cos \theta-a b \sin \theta}{b c \cos \theta+a b \sin \theta} \Rightarrow \phi=28.7 \mathrm{deg} .
$$

Then,

$$
A_{\text {Maximum }}=263.8 \mathrm{ft}^{2}
$$

\section{Convective Heat Transfer Coefficients}

The information given in this report about the heat transfer coefficient and the thermal conductivity of the waste material is from the following article.

Nuclear Safety and Heat Load Limits for Above-Grade Storage of Solid Transuranium Wastes, by B.G. Clontz, [DPSPU 77-11-24].

The above-mentioned article determined the heat load limits for the storage of solid transuranium wastes in $\mathbf{5 5}$ gallon drums within concrete culverts that are buried underground. I used these heat transfer correlations and properties to be consistent with the previously established limits.

Convective Heat Transfer Coefficients:

$$
\begin{array}{ll}
h_{\text {Horizontal }}=0.25(\Delta T)^{1 / 3} & \left(\frac{B T U}{H r \cdot \circ \cdot \cdot t^{2}}\right) \\
h_{\text {Vertical }}=0.23(\Delta T)^{1 / 3} & \left(\frac{B T U}{H r \cdot \circ \cdot \cdot \mathrm{ft}^{2}}\right)
\end{array}
$$

Where flow is obstructed:

$$
h=\frac{0.23}{2}(\Delta T)^{1 / 3}=\frac{h_{V}}{2}
$$

Ihermal Conductivities:

$$
\left(k_{\text {waste }}\right)_{\text {conservative }}=k_{\text {air }}=0.02 \quad \frac{\mathrm{BTU}}{\mathrm{Hr} \cdot \mathrm{FF}^{\mathrm{ft}} \mathrm{ft}^{2}}
$$

I. Poly-boxes inside concrete culvert

Definition of some surface temperatures: 


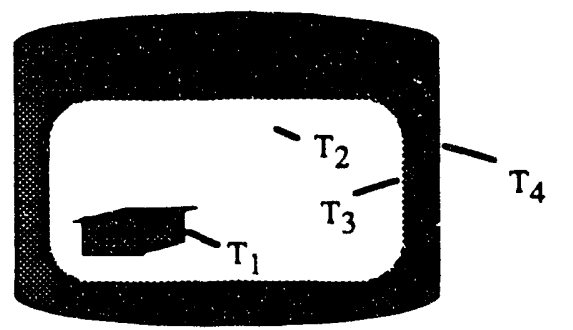

$$
T_{\infty}=110^{\circ} \mathrm{F}
$$

$T_{1}=$ Box surface temperature

$T_{2}=$ Air inside culvert temp.

$\mathrm{T}_{3}=$ Inside culvert wall temp.

$\mathrm{T}_{4}=$ Outside culvert wall temp.

$T_{\infty}=$ Worst case outdoor temp.

A. Convection from the box surface to the air inside the culvert.

( $q$ = heat generated in one polybox)

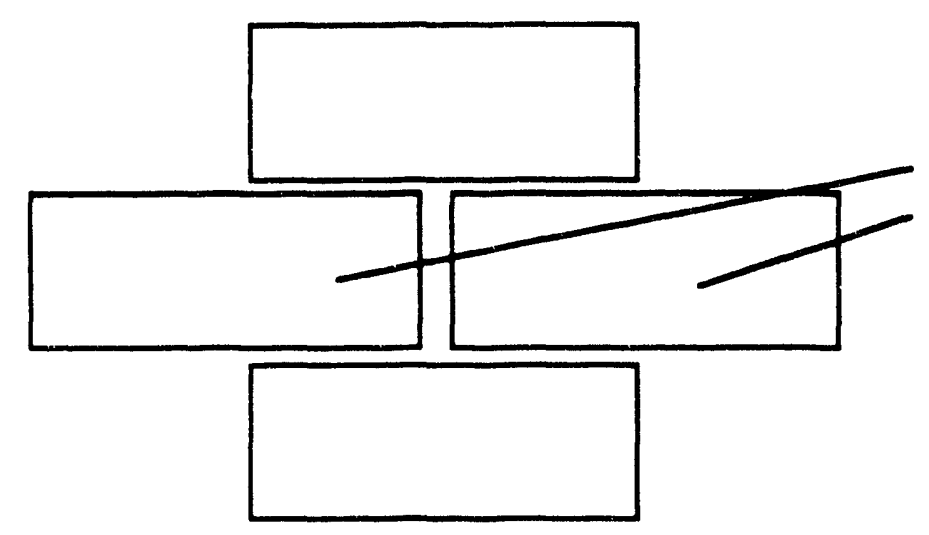

Bottom boxes at these locations are the worst case (restricted convection over half the vertical area, and no convection out the top)

$$
\begin{aligned}
& h_{V}=\frac{0.23}{2}(\Delta T)^{1 / 3} L \mid \frac{1}{2} h_{V}=0.23(\Delta T)^{1 / 3} \\
& q=\left[\left(\frac{0.23}{2}\right)\left(\frac{19.646}{2}\right)+0.23\left(\frac{19.646}{2}\right)\right]\left(T_{1}-T_{2}\right)^{4 / 3} \\
& q=3.388935\left(T_{1}-T_{2}\right)^{4 / 3}
\end{aligned}
$$

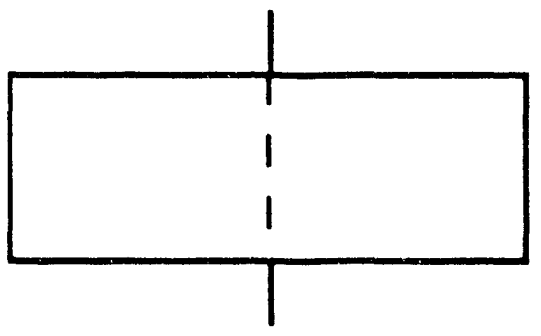

or

$$
T_{1}=T_{2}+\left[\frac{q}{3.388935}\right]^{\frac{3}{4}}
$$

B. Convection to culvert inner wall surface: 
WSRC-TR-93-174, Rev. 0

$$
\begin{gathered}
8 q=h_{V} A_{V}\left(T_{2}-T_{3}\right)+h_{H} A_{H}\left(T_{2}-T_{3}\right) \\
=(.23)(125.92)\left(T_{2}-T_{3}\right)^{4 / 3}+(.25)(29.87)\left(T_{2}-T_{3}\right)^{4 / 3} \\
q=455364\left(T_{2}-T_{3}\right)^{4 / 3} \\
\quad T_{2}=T_{3}+\left(\frac{q}{4.55364}\right)^{3 / 4}
\end{gathered}
$$

or,

C. Conduction through the concrete culvert walls and lid:

$$
\begin{aligned}
& 8 q=k \frac{2 \pi H}{\operatorname{Ln}\left(\frac{r_{0}}{r_{i}}\right)}\left(T_{3}-T_{4}\right)+k \frac{\pi r^{2}}{\tau}\left(T_{3}-T_{4}\right) \\
& 8 q=\left[\frac{(0.4) 2 \pi(6.5)}{\operatorname{Ln}\left(\frac{3.6666}{3.08333}\right)}+\frac{(0.4) \pi(3.08333)^{2}}{0.58333}\right]\left(T_{3}-T_{4}\right) \\
& q=14.346\left(T_{3}-T_{4}\right) \quad \text { or, } \quad T_{3}=T_{4}+\frac{q}{14.346}
\end{aligned}
$$

D. Convection and radiation from outer wall to atmosphere:

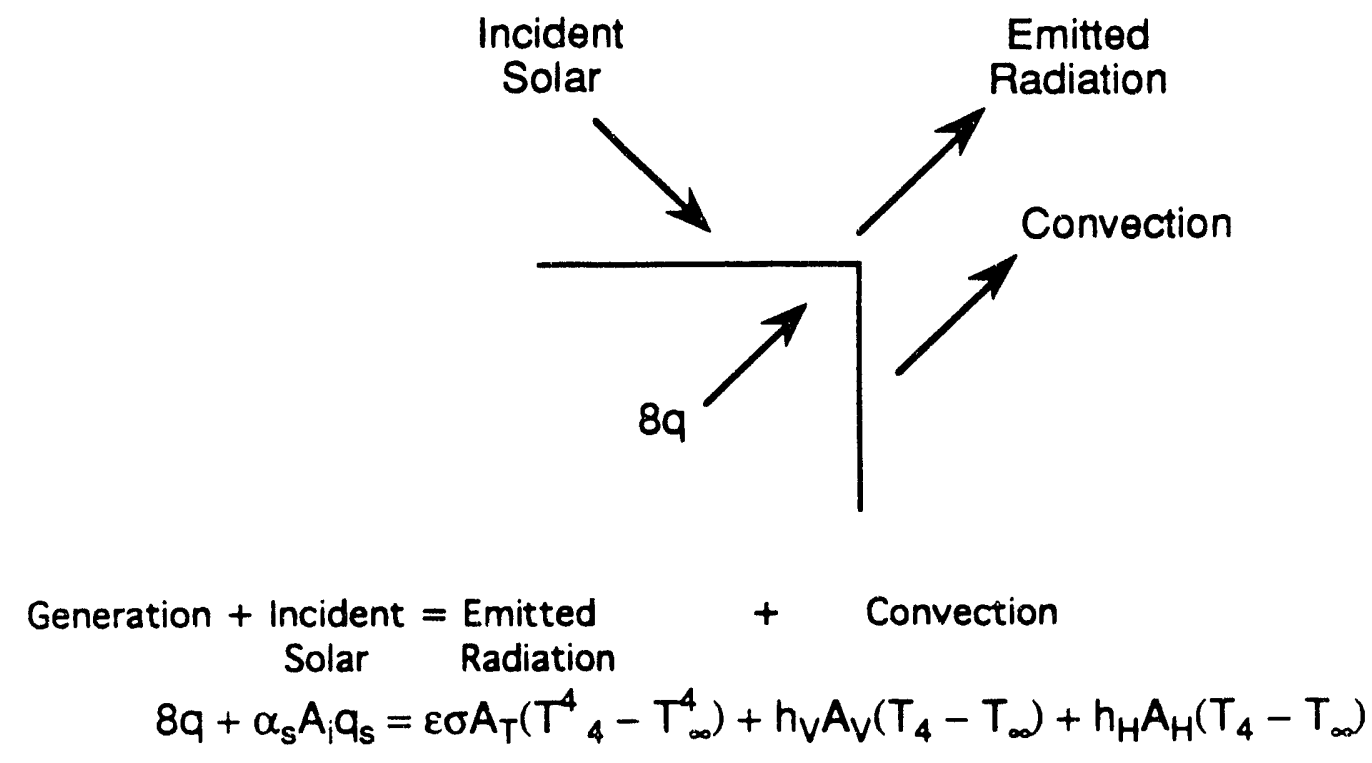




$$
\begin{aligned}
8 q+\alpha_{s}(70.32)(0.9442)=\varepsilon(0.17 & \left.14 \times 10^{-8}\right)(42.24+176.63)\left(\left(T_{4}+459.67\right)^{4}-569.67^{4}\right) \\
& +(0.23)(176.63)\left(T_{4}-110\right)^{4 / 3} \\
& +(0.25)(42.24)\left(T_{4}-110\right)^{4 / 3}
\end{aligned}
$$

Summarizing:

$$
\begin{aligned}
& T_{1}= T_{2}+\left(\frac{q}{3.388925}\right)^{3 / 4} \\
& T_{2}= T_{3}+\left(\frac{q}{4.55364}\right)^{3 / 4} \\
& T_{3}= T_{4}+\left(\frac{q}{14.346}\right) \\
& 8 q+\alpha_{s}(70.32)(0.9442)=\varepsilon\left(0.1714 \times 10^{-8}\right)(218.87)\left(\left(T_{4}+459.67\right)^{4}-569.67^{4}\right) \\
&+51.1849\left(T_{4}-110\right)^{4 / 3}
\end{aligned}
$$

\section{Drums Inside Concrete Culverts:}

There are 14 drums inside a concrete culvert in two layers of 7 drums per layer. The concrete culvert is outdoors on an open tru pad.

\section{Temperature \\ Definitions:}

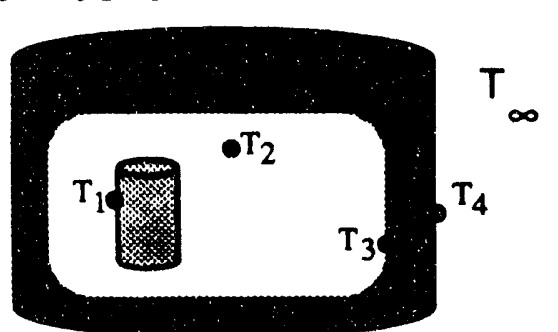

$$
\begin{aligned}
& T_{1}=\text { Drum Surface Temperature } \\
& T_{2}=\text { Air Inside Culvert Temp. }
\end{aligned}
$$$$
\mathrm{T}_{3}=\text { Inner Culvert Wall Temp. }
$$$$
\mathrm{T}_{4}=\text { Outer Culvert Wall Temp. }
$$$$
T_{\infty}=\text { Ambient Air }\left(=110^{\circ} \mathrm{F}\right) \text { Worst Case }
$$

A. Convection From the Drum Surface to the Inside Culvert.

Worst Case: Center bottom drum has restricted convection and only convects from vertical surface.

$$
A_{H}=0 \quad A_{V}=18.85 \quad h_{V}=\frac{0.23}{2}(\Delta T)^{1 / 3}
$$

Then, 


$$
q=\frac{0.23}{2}(18.85)\left(T_{1}-T_{2}\right)^{4 / 3}
$$

or,

$$
T_{1}=T_{2}+\left(\frac{q}{2.16775}\right)^{3 / 4}
$$

B. Convection From Air to Inner Culvert Wall: (Similar to Poly-box to Culvert Analysis)

$$
14 q=36.4291\left(T_{2}-T_{3}\right)^{4 / 3} \text { or, } T_{2}=T_{3}+(q / 2.60208)^{3 / 4}
$$

C. Conduction Through Culvert: (Similar to Ploy-box to Culvert Analysis)

$$
14 q=114.768\left(T_{3}-T_{4}\right) \quad \text { or, } T_{3}=T_{4}+(q / 8.1973)
$$

D. Convection and Radiation from Outer Wall to Atmosphere:

$$
\begin{aligned}
& 14 \cdot q+\alpha_{s} A_{i} q_{s}=\varepsilon \sigma A\left(T^{4}{ }_{4}-T_{\infty}^{4}\right)+ h_{V} A_{V}\left(T_{4}-T_{\infty}\right)+h_{H} A_{H}\left(T_{4}-T_{\infty}\right) \\
& 14 \cdot q+\alpha_{s}(70.32)(0.9)(442)=\varepsilon\left(0.1714 \times 10^{-8}\right)(42.24+176.63) \\
& \times\left(\left(T_{4}+459.67\right)^{4}-569.67^{4}\right) \\
&+0.23(176.63)\left(T_{4}-T_{\infty}\right)^{4 / 3} \\
&+ 0.25(42.24)\left(T_{4}-T_{\infty}\right)^{4 / 3}
\end{aligned}
$$

$$
\begin{aligned}
14 \cdot q+\alpha_{s}(70.32)(0.9)(442)=\varepsilon\left(0.1714 \times 10^{-8}\right)(42.24+176.63) \\
\times\left(\left(T_{4}+459.67\right)^{4}-569.67^{4}\right) \\
+51.1849\left(T_{4}-T_{\infty}\right)^{4 / 3}
\end{aligned}
$$

Summarizing: 


$$
\begin{aligned}
& T_{1}=T_{2}+\left(\frac{q}{2.16775}\right)^{3 / 4} \\
& T_{2}=T_{3}+\left(\frac{q}{2.60208}\right)^{3 / 4} \\
& T_{3}=T_{4}+\left(\frac{q}{8.1973}\right)
\end{aligned}
$$$$
14 \cdot q+\alpha_{s}(70.32)(0.9)(442)=\varepsilon\left(0.1714 \times 10^{-8}\right)(42.24+176.63)
$$$$
\times\left(\left(T_{4}+459.67\right)^{4}-569.67^{4}\right)
$$$$
+51.1849\left(T_{4}-T_{\infty}\right)^{4 / 3}
$$

\section{Drums on Enclosed Tru Pads.}

In this scenario, drums are stacked 2 high on a tru pad that is enclosed with a PVC-coated polyester cover (see OPS-WMT-900495 for enclosure details).

A. The Total Surface Area of the Enclosure Outer Cover is Given Next

$$
\begin{aligned}
& A_{\text {Total }}=2\left(A_{\text {Doors }}\right)+A_{\text {Sides \& Top }} \\
& \begin{array}{l}
A_{T}=2[(60)(25.95)-2(1 / 2)((12.95)(2.28)+(11.39)(6.58)+(7.25)(5.66))] \\
\quad+(160)(2)(13.149+13.154+9.1977+9.84)
\end{array} \\
& A_{T}=2(1557-145.5072)+320(45.3407) \\
& A_{\text {Total }}=17332 \mathrm{tt}^{2}
\end{aligned}
$$

(See figure on next page for details)

B. The Area for Incident Solar Radiation is Given As:

$$
A_{s}=1 \text { door }+\left(60^{\prime} \times 160^{\prime}\right) \quad \begin{aligned}
& \text { Conservative: Larger Than Actual } \\
& \text { Incident Area }
\end{aligned}
$$

$$
A_{s}=1411.4928+9600=11011.5 \mathrm{ft}^{2}
$$




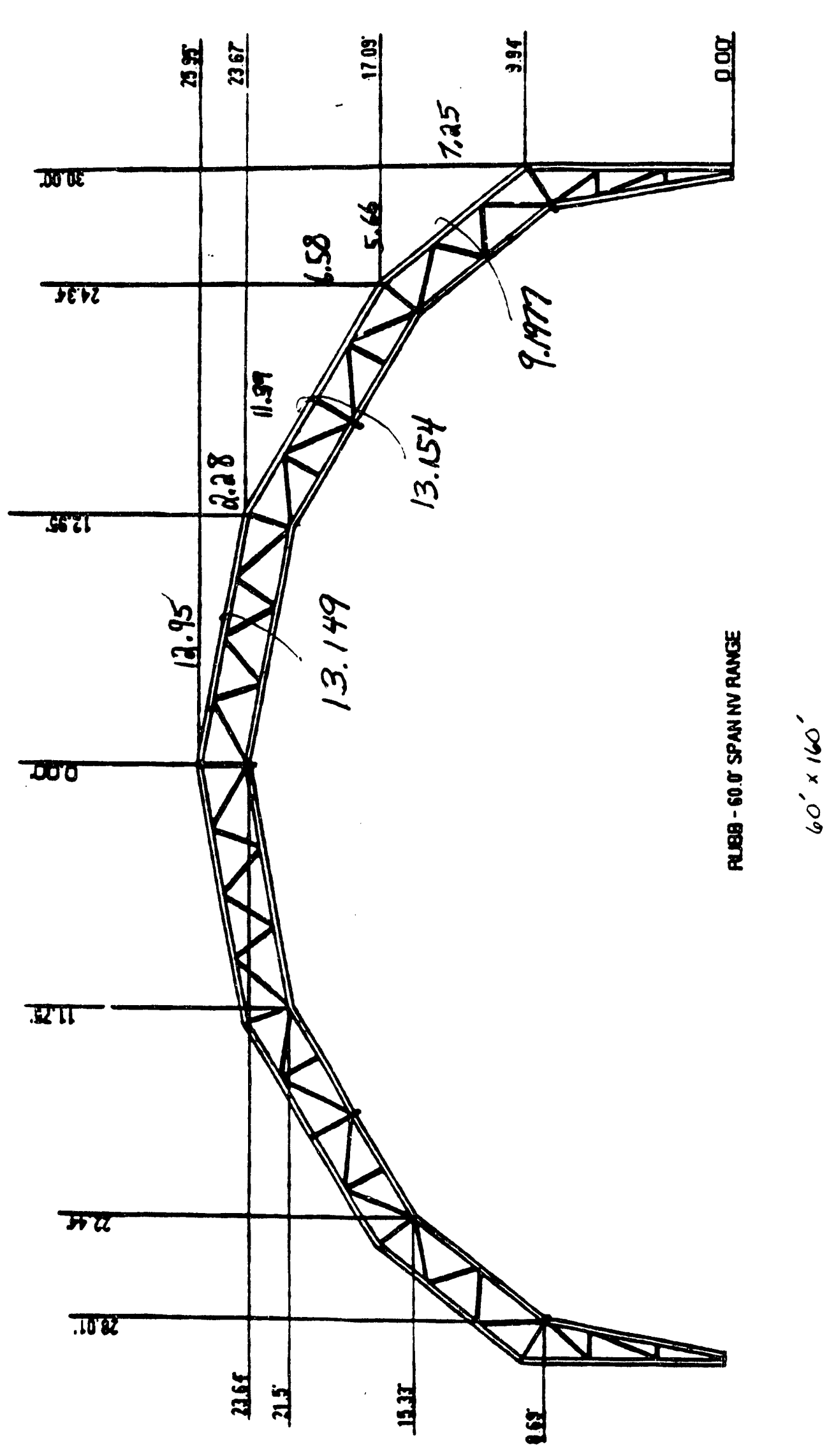


C. For convective heat transfer from the enclosures cover, the vertical heat transfer coefficient will be used with the total area. This is a conservative simplification for the complex shape of the enclosure.

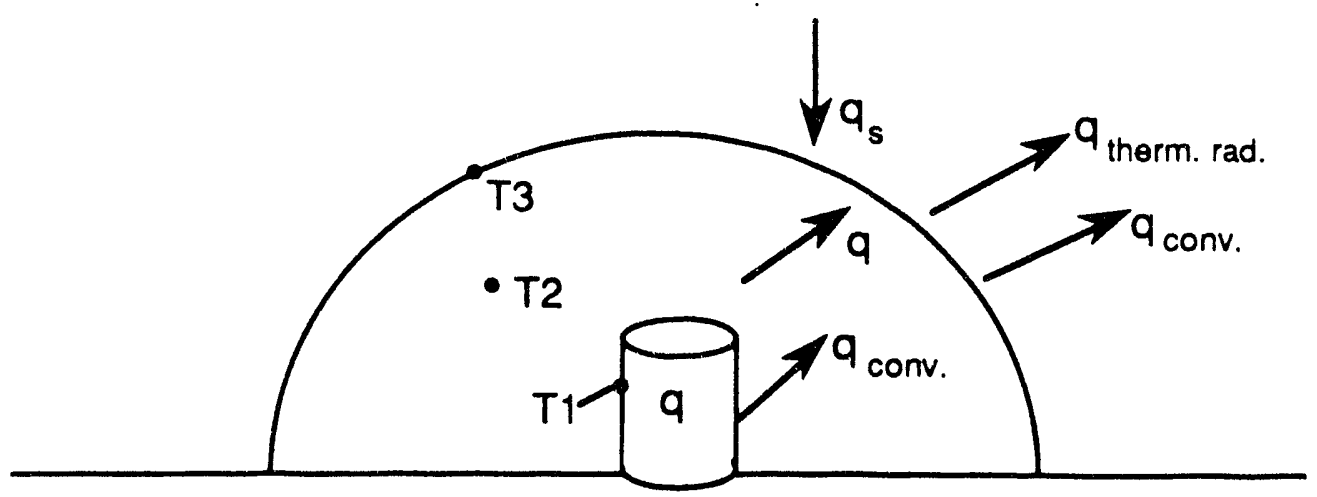

D. Convection from the Drums: $(m=\#$ of stacks $)(2 m=$ total drums $)$

Worst Case: Drum at bottom-inside row gets inhibited convection along vertical surface and no convection along horizontal surface.

$$
\begin{aligned}
& q=\left(\frac{.23}{2}\right)(18.85)\left(T_{1}-T_{2}\right)_{3}^{4} \\
& \text { or, } \quad T_{1}=T_{2}+(q / 2.16775)^{3 / 4}
\end{aligned}
$$

E. From Air to Cover:

$$
\begin{aligned}
2 q m & =(.23)(17332.01)\left(T_{2}-T_{3}\right)^{4 / 3} \\
q & =\frac{1993.18}{m}\left(T_{2}-T_{3}\right)_{3}^{4} \\
T_{2} & =T_{3}+\left(\frac{q m}{1993.18}\right)^{3}
\end{aligned}
$$

The maximum number of drums on any tru pad is given as 4200 . Therefore, $m=2100$ number of stacks.

Then, 
WSRC-TR-93-174, Rev. 0

Page 37 of 42

$$
T_{2}=T_{3}+\left(\frac{q}{0.94913}\right)^{\frac{3}{4}}
$$

F. The Cover

$$
\begin{aligned}
& 2 q m+\alpha_{s} A_{s} q_{s}=\varepsilon \sigma A\left(T^{4}{ }_{3}-T_{\infty}^{4}\right)+h_{V} A_{T}\left(T_{3}-T_{\infty}\right) \\
& \begin{array}{r}
2 q(2100)+\alpha_{s}(11011.5)(0.9)(442)= \\
\varepsilon\left(0.1714 \times 10^{-8}\right)(17332)\left(\left(T_{3}+459.67\right)^{4}-569.67^{4}\right) \\
+0.23(17332)\left(T_{3}-110\right)^{4 / 3}
\end{array}
\end{aligned}
$$

Summarizing:

$$
\begin{aligned}
& T_{1}=T_{2}+\left(\frac{q}{2.16775}\right)^{\frac{3}{4}} \\
& T_{2}=T_{3}+\left(\frac{q}{0.94913}\right)^{\frac{3}{4}}
\end{aligned}
$$

$$
\begin{aligned}
& 4200 q+\alpha_{s}(11011.5)(0.9)(442)= \\
& \varepsilon\left(0.1714 \times 10^{-8}\right)(17332)\left(\left(T_{3}+459.67\right)^{4}-569.67^{4}\right) \\
&+ 3986.36\left(T_{3}-110\right)^{4 / 3}
\end{aligned}
$$

IV. Black Boxes on Open Thru Pad: 


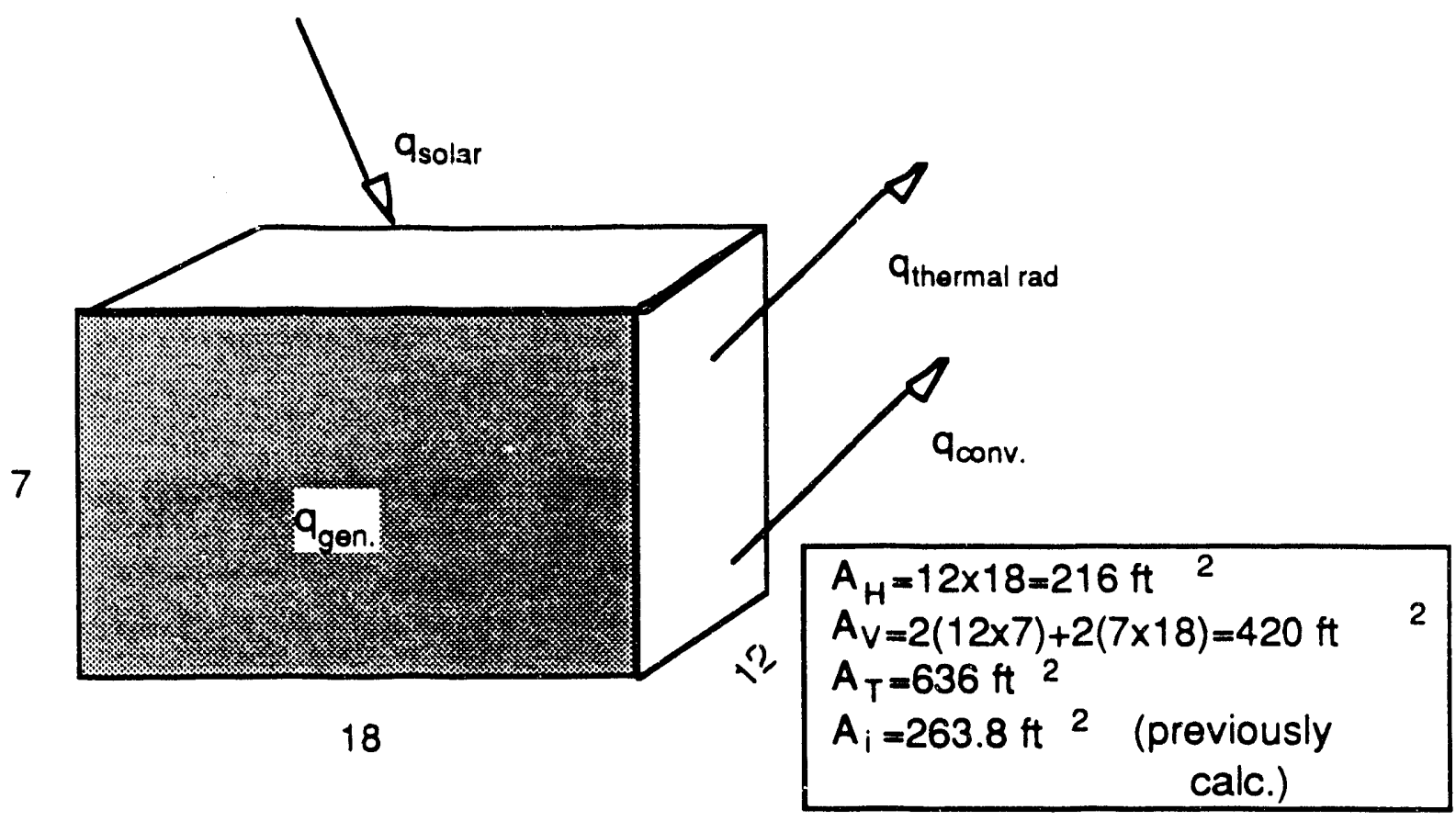

$$
\begin{aligned}
q+\alpha_{s} A_{i} q_{s}=\varepsilon \sigma A_{T}\left(T_{s}^{4}-T_{\infty}^{4}\right) & +h_{H} A_{H}\left(T_{s}-T_{\infty}\right)+h_{V} A_{V}\left(T_{s}-T_{\infty}\right) \\
q+\alpha_{s}(265)(0.9)(442)=\varepsilon(0.17 & \left.14 \times 10^{-8}\right)(636)\left(\left(T_{s}+459.67\right)^{4}-569.67^{4}\right) \\
& +0.23(420)\left(T_{s}-110\right)^{4 / 3} \\
& +0.2 j(216)\left(T_{s}-110\right)^{4 / 3}
\end{aligned}
$$

Simplifying:

$$
\begin{gathered}
q+\alpha_{s}(265)(0.9)(442)=\varepsilon\left(0.1714 \times 10^{-8}\right)(636)\left(\left(T_{s}+459.67\right)^{4}-569.67^{4}\right) \\
+150.6\left(T_{s}-110\right)^{4 / 3}
\end{gathered}
$$

\section{Temperature Profile Within The Individual Container}

The surface temperatures of a particular drum or box configuration as a function of the heat generated in that container is given in the previous analysis. The customer is interested in knowing what the heat load limits are for a particular container, if all the heat is generated in one 'cut'. A cut is a bag of waste that can be idealized by a sphere of radius $0.54 \mathrm{ft}$. To simplify this analysis, I will assume spherical conduction and conduction with generation. 


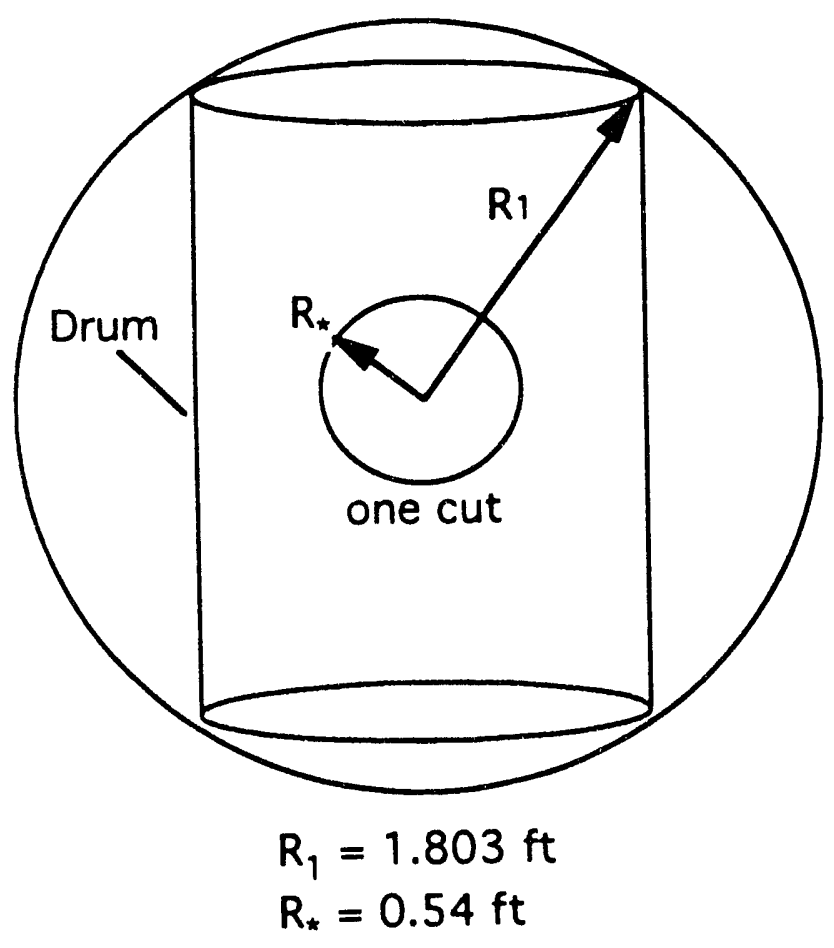

HEPA Filter

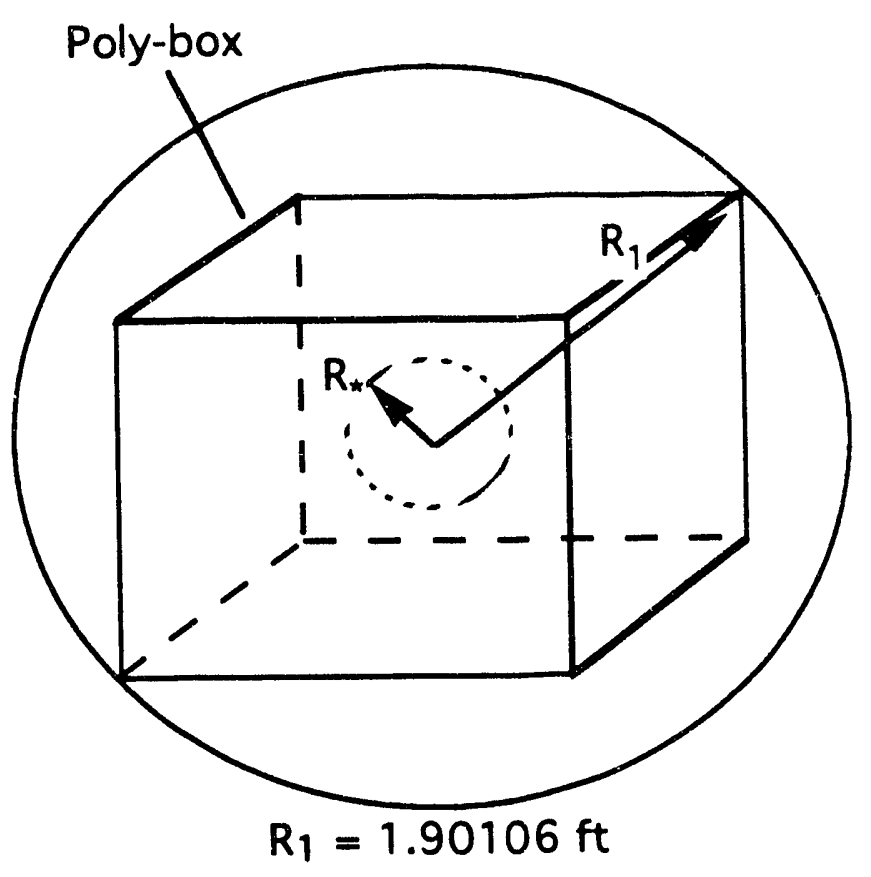

For pure conduction from $R_{\star}$ to $R_{1}$ :

$$
T_{*}=T_{1}+\frac{q}{4 \pi k}\left(\frac{1}{r_{*}}-\frac{1}{r_{1}}\right)
$$

For generation from $\mathrm{O}$ to $\mathrm{R}$ : 
WSRC-TR-93-174, Rev. 0

Page 40 of 42

$$
T(0)=T_{*}+\frac{q}{8 \pi k}\left(\frac{1}{r_{*}}\right)
$$

The derivation of these temperature equations follows:

The governing equation for the region surrounding the cut is a spherical, pure conduction, equation. This applies from the outside of the cut, at the center of the drism (or box), to the surface of the imaginary sphere that encompasses the drum (or box).

$$
\frac{d}{d r}\left(r^{2} \frac{d T}{d r}\right)=0
$$

Integrating twice yields:

$$
T(r)=\frac{C_{1}}{r}+C_{2}
$$

Applying boundary condition:

$$
\begin{array}{ll}
T\left(r=r_{1}\right)=T_{1} & \text { Drum Surface Temp. } \\
T\left(r=r_{*}\right)=T . & \text { Cut Surface Temp. }
\end{array}
$$

$$
C_{1}=\frac{T_{1}-T}{\left(\frac{1}{r_{1}}-\frac{1}{r_{0}}\right)}
$$

$$
C_{2}=T_{1}-\frac{T_{1}-T}{\left(1-\frac{r_{1}}{r_{*}}\right)}
$$

After simplifying, the temperature profile is:

$$
T(r)=\left[\frac{T_{1}-T_{*}}{\left(1-\frac{r_{1}}{r_{*}}\right)}\right]\left(\frac{r_{1}}{r}\right)+T_{1}-\left[\frac{T_{1}-T_{*}}{\left(1-\frac{r_{1}}{r_{*}}\right)}\right]
$$

or,

$$
\begin{aligned}
& T(r)=T_{1}+\left[\frac{T_{1}-T_{-}}{\left(1-\frac{r_{1}}{r_{*}}\right)}\right]\left(\frac{r_{1}}{r}-1\right) \\
& \frac{d T}{d r}=\left[\frac{T_{1}-T_{0}}{\left(1-\frac{r_{1}}{r_{*}}\right)}\right]\left(\frac{-r_{1}}{r^{2}}\right)
\end{aligned}
$$


At $r=r *$ (the flux leaving the cut $)=($ flux entering rest of drum $)$

Determination of temperature profile within a cut and within the nongererating surface around the cut.

The governing equation for the sphere (cut) with heat generation is as follows:

$$
k \frac{1}{r^{2}} \frac{d}{d r}\left|r^{2} \frac{d T}{d r}\right|+q^{\prime \prime \prime}=9 \text { where: } \quad q^{\prime \prime}=\frac{q}{\forall}
$$

Integrating twice yields:

$$
T(r)=-\frac{q^{111}}{6 K} r^{2}+\frac{C_{1}}{r}+C_{2}
$$

Boundary conditions: $T(r+0)=r o \Rightarrow C_{1}=0 \quad C_{2}=T_{0}$

$$
T(r)=T_{0}-\frac{q^{\prime \prime}}{6 K} r^{2}
$$

and $\frac{d T}{d r}=-\frac{q^{\prime \prime}}{3 K} r$

If I know that $T$ at $r=r *$ (cut boundary), then I can find $T_{0}$ from thie boundary condition $T\left(r=r_{*}\right)=T_{*}$

$$
T_{0}=T_{0}-\frac{q^{\prime m}}{6 K} r^{2} \quad \text { or, } T_{0}=T_{*}+\frac{q^{\prime m}}{6 K} r_{*}^{2}
$$

substituting

$$
\forall=\frac{4}{3} \pi r^{2}
$$

$$
T_{0}=T_{*}+\frac{q}{8 \pi k}\left(\frac{1}{r_{*}}\right)
$$

Applying the condition of the heat flux leaving the generating region is the same as the heat flux entering the non-generating region yields the temperature at the interface between the two regions. 
$\left(-\left.k \frac{d T_{*}}{d r}\right|_{r_{\cdot}}\right)_{\text {generating region }}=\left(-\left.k \frac{d T}{d r}\right|_{r_{\cdot}}\right)_{\text {non-generating region }}$

The conductivity is the same for both regions

$$
-\left(\frac{-q^{\prime \prime \prime}}{3 k} r_{*}\right)=-\left(\frac{T_{1}-T_{*}}{1-\frac{r_{1}}{r_{*}}}\right)\left(-\frac{r_{1}}{r_{*}^{2}}\right)
$$

substituting;

$$
\begin{gathered}
q^{\prime \prime \prime}=\frac{q}{\frac{4}{3} \pi r_{*}^{3}} \\
\frac{-q r_{*}}{\left(\frac{4}{3} \pi r_{*}^{3}\right)(3 k)}=\frac{-\left(T_{1}-T_{*}\right)}{\left(1-\frac{r_{1}}{r_{*}}\right)}\left(\frac{r_{1}}{r_{*}^{2}}\right)
\end{gathered}
$$

simplifying some yields:

$$
\frac{-\mathrm{q}}{4 \pi \mathrm{k}}=\frac{\mathrm{T}_{*}-\mathrm{T}_{1}}{\left(\frac{1}{r_{1}}-\frac{1}{r_{*}}\right)}
$$

or,

$$
T_{*}=T_{1}+\frac{q}{4 \pi k}\left(\frac{1}{r_{*}}-\frac{1}{r_{1}}\right)
$$

Then the following two equations give the temperature profile within the generating and non-generating regions of the drum (or box)

At $r=0$;

$$
T_{0}=T_{*}+\frac{q}{8 \pi k}\left(\frac{1}{r_{*}}\right)
$$

At $r=r_{*}$;

$$
T_{*}=T_{1}+\frac{q}{4 \pi k}\left(\frac{1}{r_{*}}-\frac{1}{r_{1}}\right)
$$



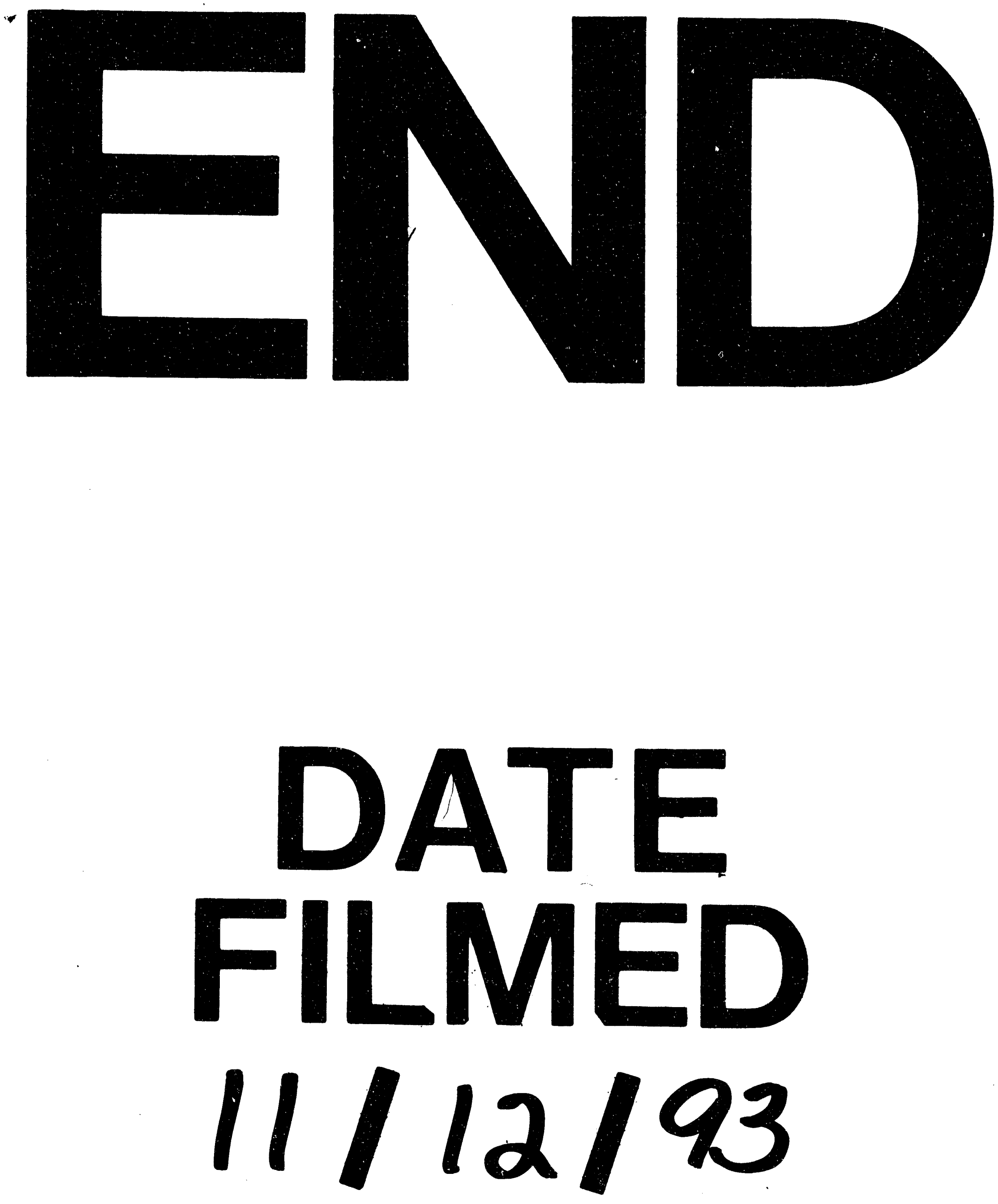
